\title{
Glaucoma Syndromes: Insights into Glaucoma Genetics and Pathogenesis from Monogenic Syndromic Disorders
}

\author{
Daniel A. Balikov ${ }^{1}$, Adam Jacobson ${ }^{1}$ (D) and Lev Prasov 1,2,*(D) \\ 1 Department of Ophthalmology and Visual Sciences, University of Michigan, Ann Arbor, MI 48105, USA; \\ dbalikov@med.umich.edu (D.A.B.); adajac@med.umich.edu (A.J.) \\ 2 Department of Human Genetics, University of Michigan, Ann Arbor, MI 48109, USA \\ * Correspondence: lprasov@umich.edu
}

Citation: Balikov, D.A.; Jacobson, A.; Prasov, L. Glaucoma Syndromes: Insights into Glaucoma Genetics and Pathogenesis from Monogenic Syndromic Disorders. Genes 2021, 12, 1403. https://doi.org/10.3390/ genes12091403

Academic Editor: Joan M. O’Brien

Received: 30 July 2021

Accepted: 8 September 2021

Published: 11 September 2021

Publisher's Note: MDPI stays neutral with regard to jurisdictional claims in published maps and institutional affiliations.

Copyright: (c) 2021 by the authors. Licensee MDPI, Basel, Switzerland. This article is an open access article distributed under the terms and conditions of the Creative Commons Attribution (CC BY) license (https:// creativecommons.org/licenses/by/ $4.0 /)$.

\begin{abstract}
Monogenic syndromic disorders frequently feature ocular manifestations, one of which is glaucoma. In many cases, glaucoma in children may go undetected, especially in those that have other severe systemic conditions that affect other parts of the eye and the body. Similarly, glaucoma may be the first presenting sign of a systemic syndrome. Awareness of syndromes associated with glaucoma is thus critical both for medical geneticists and ophthalmologists. In this review, we highlight six categories of disorders that feature glaucoma and other ocular or systemic manifestations: anterior segment dysgenesis syndromes, aniridia, metabolic disorders, collagen/vascular disorders, immunogenetic disorders, and nanophthalmos. The genetics, ocular and systemic features, and current and future treatment strategies are discussed. Findings from rare diseases also uncover important genes and pathways that may be involved in more common forms of glaucoma, and potential novel therapeutic strategies to target these pathways.
\end{abstract}

Keywords: juvenile open-angle glaucoma; pediatric glaucoma; Singleton-Merten syndrome; AicardiGoutieres syndrome; aniridia; mucopolysaccharidosis; Peter's anomaly; osteogenesis imperfecta; Stickler syndrome; nanophthalmos; anterior segment dysgenesis; Axenfeld-Rieger syndrome

\section{Introduction}

Glaucoma comprises a group of disorders characterized by optic neuropathy resulting from retinal ganglion cell death in a specific pattern. Glaucoma is generally classified into two main categories: open angle, in which the iridociliary drainage angle is open, and angle closure glaucoma, in which the angle is obstructed. Though there are many risk factors contributing to glaucoma, including age, sex, ethnicity, blood pressure, medications, and elevated intraocular pressure, there is an additional strong genetic component [1]. Because of its progressive and irreversible nature, glaucoma is the leading cause of permanent vision loss worldwide [2]. At present, nearly 60 million people worldwide are thought to have glaucoma. This number is likely an underestimate as glaucoma is underdiagnosed in certain populations $[3,4]$.

Childhood glaucoma comprises a small, but significant fraction of the total population of glaucoma patients [5]. Glaucoma affecting infants and children, including primary congenital glaucoma (PCG) and juvenile open-angle glaucoma (JOAG), is estimated to affect 1:10,000 to 1:100,000 children worldwide [6-8], with higher incidence in areas with increased consanguineous marriages [9]. It represents a high disease burden, contributing to $5-18 \%$ of childhood blindness [5]. Childhood glaucoma may be more difficult to diagnose given that standard ophthalmic testing performed for glaucoma is difficult to perform in children, and the precise pathogenic mechanisms are difficult to define. Angle procedures such as goniotomy or trabeculotomy are typically the first line treatments, but these are often ineffective in some subtypes if downstream outflow pathways are affected, as is common in many secondary glaucomas. Many childhood glaucomas are associated with monogenic systemic syndromes, which can offer important clues into the etiology and 
mechanisms of this group of diseases by identifying specific genes and pathways important in ocular structure and function. In this review, we outline several broad classes of childhood glaucoma that have syndromic presentations, discuss their underlying genetic findings, and present the state of the art and limitations for diagnosis and treatment.

\section{Syndromes}

2.1. Anterior Segment Dysgenesis Syndromes

2.1.1. Axenfeld-Rieger Syndrome

Axenfeld-Reiger syndrome (ARS) was first documented as a specific constellation of pathologies in 1920 by Axenfeld but later addended by Rieger in $1934[10,11]$. Two predominant genes, paired-like homeodomain 2 (PITX2) and forkhead box C1 (FOXC1), have been described to cause the vast majority of ARS (nearly $60 \%$ of all cases) [12-15]. PITX2 and FOXC1 both encode transcription factors that regulate gene expression during eye development [16-18] with more than 80 pathogenic variants (deletions, insertions, splice variants) in PITX2 and 50 pathogenic variants in FOXC1 have been described in ARS [19-21]. Both are inherited in an autosomal dominant manner with variable penetrance and the central pathogenic mechanism is thought to be haploinsufficiency for these transcriptional factors [22,23]. Curiously, a key study by Berry and colleagues discovered that both PITX2 and FOXC1 proteins interact with and regulate key developmental pathways (the former negatively impacting the latter) [24].

Classic ocular findings in ARS include bilateral posterior embryotoxon (the anterior displacement Schwalbe's line, the junction of cornea and sclera), corectopia, iris thinning, polycoria, and abnormal angle structures (Table 1) [25]. Nearly 50\% of children develop glaucoma $[10,26]$, and several more recent studies have demonstrated that glaucoma occurs in $20-74 \%$ of patient subjects with PITX2 pathogenic variants and $44-100 \%$ of patient subjects with $F O X C 1$ pathogenic variants $[15,27,28]$. Of note, iris hypoplasia was originally described by Berg in 1932 in a family with thin irides and a very high incidence of glaucoma (ages 16-43) [29]. Iris hypoplasia, over time, has been considered to be part of ARS due to the significant syndromic overlap with ARS and pathogenic variants in both PITX2 [30] and FOXC1 [12]. Systemically, ARS can have extraocular manifestations, the most commonly observed being facial and dental anomalies (e.g., dental hypoplasia, flat mid-face) [31], umbilical abnormalities [32], and pituitary abnormalities (e.g., empty sella syndrome and growth hormone deficiency) $[33,34]$. Less common, but known, syndromic associations include SHORT syndrome [35], short FRAME syndrome [36], cardiac defects [37], sensorineural hearing loss [38], and myotonic dystrophy [39]. Sensorineural hearing loss may be a more prevalent feature of FOXC1 mediated ARS [40]. The significant genetic heterogeneity and phenotypic variability of this condition may be attributable to stochastic events during ocular development and systemic organogenesis, with many genes and precise gene timing and dosage needed for proper anterior segment development.

Patients suspected of having ARS are always recommended to undergo genetic testing. Many common methods include chromosome analysis and DNA array comparative genomic hybridization; a modern bioinformatics analysis significantly improved detection efficacy [41]. Pathogenic variants in ARS genes FOXC1 and PITX2 make up about 40\% of ASD cases [42], but the diagnostic yield is likely higher in patients with classic ARS. Because of the complexity of the disease, there are currently no clinical trials underway for the treatment of ARS. However, clinical management does exist. Many first line therapies include glaucoma eye drops, but this is not always effective given the angle structure (as demonstrated in a retrospective study [27]). In most cases, surgical interventions to modify or bypass the angle, such as trabeculectomy or tube shunt, are the remaining options for these patients [43]. 
Table 1. Features of glaucoma syndromes.

\begin{tabular}{|c|c|c|c|}
\hline Syndrome & $\begin{array}{c}\text { Known Genes (Inheritance } \\
\text { Pattern) }\end{array}$ & Ocular Features & Systemic Features \\
\hline $\begin{array}{l}\text { Anterior segment dysgenesis } \\
\text { (including Axenfeld-Rieger } \\
\text { syndrome) }\end{array}$ & $\begin{array}{l}\text { PITX2 (AD) } \\
\text { FOXC1 (AD) } \\
\text { CPAMD8 (AR) }\end{array}$ & $\begin{array}{l}\text { Posterior embyotoxon, } \\
\text { corectopia, iris hypoplasia, } \\
\text { polycoria, dysplastic angle } \\
\text { structures, glaucoma } \\
\text { CPAMD8 with also } \\
\text { iridodonesis, ectopia lentis, } \\
\text { ectropion uvea }\end{array}$ & $\begin{array}{l}\text { Axenfeld-Rieger syndrome: } \\
\text { dental hypoplasia, flat } \\
\text { mid-face, umbilical } \\
\text { abnormalities, pituitary } \\
\text { abnormalities, cardiac defects, } \\
\text { sensorineural hearing loss, } \\
\text { myotonic dystrophy }\end{array}$ \\
\hline Peters Anomaly & $\begin{array}{l}\text { PITX2 (AD) } \\
\text { FOXC1 (AD) } \\
\text { PAX6 (AD) } \\
\text { CYP1B1 (AD/AR) } \\
\text { B3GALTL (AR) }\end{array}$ & $\begin{array}{l}\text { Central corneal opacities, iris } \\
\text { synechiae, absence of corneal } \\
\text { endothelium, absence of } \\
\text { descemet membrane, } \\
\text { glaucoma }\end{array}$ & $\begin{array}{l}\text { Peters Plus syndrome: short } \\
\text { stature, abnormal ears, } \\
\text { brachyomorphism }\end{array}$ \\
\hline Aniridia & $\begin{array}{l}\text { PAX6 (AD/AR) } \\
\text { ITPR1 (AD/AR) } \\
\text { FOXC1 (AD) } \\
\text { PITX2 (AD) }\end{array}$ & $\begin{array}{l}\text { Iris hypoplasia (total or } \\
\text { partial), limbal stem cell } \\
\text { deficiency, keratopathy, } \\
\text { cataracts, foveal hypoplasia, } \\
\text { optic nerve hypoplasia, } \\
\text { nystagmus, glaucoma }\end{array}$ & $\begin{array}{l}\text { WAGR syndrome: Wilms } \\
\text { tumor, genitourinary } \\
\text { abnormalities, mental } \\
\text { retardation } \\
\text { Gillespie syndrome: } \\
\text { Cerebellar ataxia, intellectual } \\
\text { disability }\end{array}$ \\
\hline Stickler Syndrome & $\begin{array}{l}\text { COL2A1 (AD) } \\
\text { COL11A1 (AD) } \\
\text { COL9A1 (AR) } \\
\text { COL9A2 (AR) }\end{array}$ & $\begin{array}{l}\text { Myopia, cataracts, retinal } \\
\text { detachments, elongated ciliary } \\
\text { processes, glaucoma }\end{array}$ & $\begin{array}{l}\text { Midface hypoplasia, cleft } \\
\text { palate, glossoptosis, } \\
\text { sensorineural hearing loss, } \\
\text { short stature, arthropathy }\end{array}$ \\
\hline Osteogenesis Imperfecta & $\begin{array}{l}\text { COL1A1 (AD) } \\
\text { COL1A2 (AD) } \\
\text { IFITM5 (AD) }\end{array}$ & $\begin{array}{l}\text { Corneal thinning, scleral } \\
\text { thinning (blue sclera), low } \\
\text { ocular rigidity short axial } \\
\text { length, retinal detachment, } \\
\text { glaucoma }\end{array}$ & $\begin{array}{l}\text { Bone fragility, low bone } \\
\text { mineral density skeletal } \\
\text { deformities, dentinogenesis } \\
\text { imperfecta, hyperlaxity of } \\
\text { ligaments, cardiovascular } \\
\text { disease, hearing loss }\end{array}$ \\
\hline $\begin{array}{l}\text { COL4A1-associated } \\
\text { connective tissue disorder }\end{array}$ & COL4A1 (AD) & $\begin{array}{l}\text { Anterior segment dysgenesis } \\
\text { similar to Axenfeld-Rieger } \\
\text { syndrome }\end{array}$ & $\begin{array}{l}\text { Cerebrovascular } \\
\text { abnormalities, } \\
\text { leukoencephalopathy, cardiac } \\
\text { abnormalities, renal } \\
\text { abnormalities, muscular } \\
\text { abnormalities }\end{array}$ \\
\hline TEK/ANGPT1-glaucoma & $\begin{array}{l}\text { TEK (AD) } \\
\text { ANGPT1 (AD) }\end{array}$ & Primary congenital glaucoma & None \\
\hline $\begin{array}{l}\text { Aicardi-Goutieres } \\
\text { Syndrome }\end{array}$ & $\begin{array}{l}\text { TREX1 (AR) } \\
\text { RNASEH2A (AR) } \\
\text { RNASEH2B (AR) } \\
\text { RNASEH2C (AR) } \\
\text { SAMHD1 (AR) } \\
\text { ADAR (AR) } \\
\text { IFIH1 (AD) }\end{array}$ & $\begin{array}{l}\text { Congenital glaucoma, optic } \\
\text { atrophy, cortical blindness }\end{array}$ & $\begin{array}{l}\text { Encephalopathy, } \\
\text { microcephaly leukodystrophy, } \\
\text { cerebral atrophy, intracranial } \\
\text { calcifications, } \\
\text { hepatosplenomegaly, } \\
\text { thrombocytopenia, lupus-like } \\
\text { syndrome }\end{array}$ \\
\hline Singleton-Merten Syndrome & $\begin{array}{l}\text { DDX58 (AD) } \\
\text { IFIH1 }(A D)\end{array}$ & $\begin{array}{l}\text { Congenital or juvenile } \\
\text { open-angle glaucoma } \\
\text { Ocular surface disease }\end{array}$ & $\begin{array}{l}\text { Psoriasiform rash, vascular } \\
\text { calcifications skeletal } \\
\text { dysplasia, tendon rupture, } \\
\text { arthritis, dental anomalies }\end{array}$ \\
\hline
\end{tabular}


Table 1. Cont.

\begin{tabular}{|c|c|c|c|}
\hline Syndrome & $\begin{array}{c}\text { Known Genes (Inheritance } \\
\text { Pattern) }\end{array}$ & Ocular Features & Systemic Features \\
\hline Nanophthalmos & $\begin{array}{l}\text { MFRP (AR) } \\
\text { PRSS56 (AR) } \\
\text { BEST1 (AR) } \\
\text { TMEM98 (AD) } \\
\text { CRB1 (AR) } \\
\text { MYRF (AD) } \\
\text { FAM111A (AR) }\end{array}$ & $\begin{array}{l}\text { Axial hyperopia, esotropia, } \\
\text { foveal hypoplasia, optic disc } \\
\text { drusen, } \\
\text { retinoschisis/foveoschisis, } \\
\text { retinitis pigmentosa, } \\
\text { chorioretinal folds, central } \\
\text { retinal vein occlusions, angle } \\
\text { closure glaucoma }\end{array}$ & $\begin{array}{l}\text { Cardiac-urogenital syndrome } \\
\text { (CUGS): Diaphragmatic } \\
\text { hernia, cardiopulmonary } \\
\text { vascular anomalies (i.e., } \\
\text { Scimitar syndrome), } \\
\text { pulmonary hypoplasia, } \\
\text { urogenital anomalies } \\
\text { Kenny-Caffey syndrome: } \\
\text { skeletal dysplasia, short } \\
\text { stature, hypocalcemia, } \\
\text { microorchidism }\end{array}$ \\
\hline
\end{tabular}

AD: autosomal dominant; AR: autosomal recessive.

\subsubsection{Peters Anomaly}

Peters anomaly (PA) is a heterogenous genetic disorder associated with at least eight different genes [44]. The most common genes include PITX2 [14], FOXC1 [12,13], PAX6 [45,46], CYP1B1 [47], and B3GALTL [48]. Inheritance of gene pathogenic variants for $\mathrm{PA}$ are also heterogenous with autosomal dominant, autosomal recessive, and sporadic patterns of inheritance $[49,50]$. It is believed that failure of the lens separation from the surface ectoderm during early eye development gives rise to the ocular manifestations of the disease [51]. Clinically, many ocular findings for PA can be subtle. With careful ophthalmic examination, patients can have unilateral or bilateral absence of corneal endothelium, absence of the Descemet membrane, central corneal opacities, and iris synechiae [50,52]. Patients with PA have an incidence rate of glaucoma of nearly $50 \%$, although it is rarely found at birth. With respect to syndromic manifestations, extraocular findings are defined in Peters Plus, which includes short stature, abnormal ears, brachydactyly [53], cleft lip/palate, facial dysmorphia, Potter syndrome, dextrocardia, and hydrocephalus [54-57].

Treatment for PA is also limited to the same treatments as ARS. As reviewed by Dolezal and colleagues, many patients require surgical intervention in order to address intraocular pressure [58]. Surgeries employed include trabeculotomy, trabeculectomy, tube shunts, as well as cycloablation of the ciliary body. However, the success rates for surgical intervention rarely exceed 50\% ( $0 \%$ trabeculotomy, 25\% trabeculectomy, and 53\% for tube shunt), suggesting that tube shunts are the optimal conventional treatment, but novel approaches are being attempted [59].

\subsubsection{CPAMD8-Associated Anterior Segment Dysgenesis}

It should be noted, however, that other mutated genes have been implicated in this spectrum that account for the remaining $40 \%$ of cases other than ARS and PA [25]. Most recently, C3 and PZP-like alpha-2-macroglobulin domain-containing protein 8 (CPAMD8) was found to cause autosomal recessive anterior segment dysgenesis [60]. CPAMD8 is a protein that has been documented in corneal endothelial cells and known to play a critical role in aqueous humor dynamics (specifically found in non-pigmented epithelium of the ciliary body) [61,62]. In the discovery, pathogenic variants of CPAMD8 were a collection of missense, frameshift, and splice-site pathogenic variants. Patients across four families had unique phenotypic findings that were different than other anterior segment dysgenesis conditions. These findings included iris hypoplasia, iris transillumination defects, ectropion uveae, corectopia, iridodonesis with ectopia lentis, cataracts, normal intraocular pressure, and generally normal anterior chamber angle structure [60]. Follow-up cohort studies of children with childhood or juvenile open-angle glaucoma were found to have a low frequency of CPAMD8 pathogenic variants causing glaucoma, especially when proband families were otherwise asymptomatic for any glaucoma [63,64]. One study recently observed human biopsy samples from a patient's cadaveric eye with a CPAMD8 
pathogenic variant and discovered that the anterior chamber angle was subtlety malformed (e.g., variable thickness of the corneoscleral and uveoscleral trabecular meshwork) coupled with an unusual extracellular matrix deposition (e.g., patterns of basement membrane proteins not being uniform or aligned), and trabecular meshwork cells actively undergoing apoptosis [65]. This newly discovered gene and associated pathogenic variants leading to glaucoma provide even more insight into the multiple mechanisms in which glaucoma can develop, particularly the extracellular matrix structure. However, more studies are warranted to look at aqueous outflow in these types of patients or animal models with this pathogenic variant in order to develop new pharmaceutical therapies that can outperform conventional surgical bypass therapies.

\subsection{Metabolic Disorders}

The mucopolysaccharidoses are a collection of inherited lysosomal enzyme deficiencies resulting in an accumulation of glycosaminoglycans (GAGs) throughout the body. These disorders are traditionally classified into types I-IX, originally categorized based on the affected gene and enzyme, although as genetic analysis has become more detailed, so has the classification system [66-73]. The genetic causes of mucopolysaccharidoses have been well-elucidated despite these being very rare disorders. Each subtype is caused by a deficiency in a specific lysosomal enzyme resulting in decreased GAG catabolism and subsequent accumulation in nearly all body tissues (Table 2) [66-73]. Most mucopolysaccharidoses are inherited in an autosomal recessive or X-linked manner and represent loss-of-function enzymatic deficiencies. Of note, there are racial differences in prevalence and types of pathogenic variants, as described by Khan et al. [70].

Table 2. Clinical and molecular features mucopolysaccharidosis subtypes.

\begin{tabular}{|c|c|c|c|c|c|c|c|c|c|}
\hline Type & Subtype & Eponym & Defective Enzyme & $\begin{array}{l}\text { Accumulated } \\
\text { GAG }\end{array}$ & Gene Locus & Inheritance & $\begin{array}{l}\text { Corneal } \\
\text { Clouding }\end{array}$ & Glaucoma & $\begin{array}{c}\text { Optic } \\
\text { Neuropathy }\end{array}$ \\
\hline \multirow[t]{3}{*}{ I } & $\mathrm{IH}$ & Hurler & $\alpha$-L-Iduronidase & HS, DS & $4 \mathrm{p} 16.3$ & $\mathrm{AR}$ & $\begin{array}{c}+\rightarrow+++ \\
6 \text { months-1.1 } \\
\text { years }\end{array}$ & $\begin{array}{l}+/++ \\
1 \text { year }\end{array}$ & $\begin{array}{c}+/++ \\
17 \text { years }\end{array}$ \\
\hline & $\mathrm{I} \mathrm{H} / \mathrm{S}$ & $\begin{array}{l}\text { Hurler- } \\
\text { Scheie }\end{array}$ & $\alpha$-L-Iduronidase & HS, DS & $4 \mathrm{p} 16.3$ & $\mathrm{AR}$ & $\begin{array}{l}+/++ \\
4.4 \text { years }\end{array}$ & $\begin{array}{c}++ \\
1 \text { year }\end{array}$ & $\begin{array}{c}++ \\
17 \text { years }\end{array}$ \\
\hline & IS & Scheie & $\alpha$-L-Iduronidase & HS, DS & $4 \mathrm{p} 16.3$ & $\mathrm{AR}$ & $\begin{array}{c}+\rightarrow+++ \\
24 \text { months-10.5 } \\
\text { years }\end{array}$ & $\begin{array}{l}+/++ \\
1 \text { year }\end{array}$ & $\begin{array}{c}+/++ \\
17 \text { years }\end{array}$ \\
\hline II & & Hunter & Iduronate-2-sulfatase & HS, DS & $\mathrm{Xq} 28$ & $\mathrm{XL}$ recessive & Clear/+ & $\begin{array}{c}+ \\
7.5 \text { years }\end{array}$ & $\begin{array}{c}\text { None } \rightarrow++ \\
33 \text { years }\end{array}$ \\
\hline \multirow[t]{4}{*}{ III } & $\mathrm{A}$ & Sanfilippo A & Heparan-N-sulfatase & HS & $17 q 25.3$ & $\mathrm{AR}$ & + & + & + \\
\hline & B & Sanfilippo B & $\begin{array}{c}\alpha-\mathrm{N}- \\
\text { acetylglucosaminidase }\end{array}$ & HS & $17 q 21$ & $\mathrm{AR}$ & + & + & + \\
\hline & $\mathrm{C}$ & Sanfilippo C & $\begin{array}{l}\alpha \text {-glucosaminidase- } \\
\text { acetyltranferase }\end{array}$ & HS & $8 \mathrm{p} 11.1$ & $\mathrm{AR}$ & + & + & + \\
\hline & $\mathrm{D}$ & Sanfilippo D & $\begin{array}{l}\text { N-acetylglucosamine- } \\
\text { 6-sulfatase }\end{array}$ & HS & $12 \mathrm{q} 14$ & $\mathrm{AR}$ & $\stackrel{+}{+}+$ & + & + \\
\hline \multirow[t]{2}{*}{ IV } & A & Morquino A & $\begin{array}{l}\mathrm{N}- \\
\text { acetylgalactosamine-6- } \\
\text { sulfatase }\end{array}$ & KS & $16 \mathrm{q} 24$ & $\mathrm{AR}$ & $\stackrel{+}{+} 11$ years & $\begin{array}{c}+ \\
7.8 \text { years }\end{array}$ & None $\rightarrow+$ \\
\hline & B & Morquino B & $\beta$-galactosidase & KS & $16 \mathrm{q} 24$ & $\mathrm{AR}$ & $\stackrel{+}{+}+{ }_{11}^{\text {years }}$ & $\stackrel{+}{+}$ & None $\rightarrow+$ \\
\hline VI & & $\begin{array}{l}\text { Maroteaux- } \\
\text { Lamy }\end{array}$ & $\begin{array}{l}\mathrm{N}- \\
\text { acetylgalactosamine-4- } \\
\text { sulfatase }\end{array}$ & DS & $5 q 12$ & $\mathrm{AR}$ & $\begin{array}{c}+++ \\
7 \text { years }\end{array}$ & $\begin{array}{c}++ \\
3 \text { years }\end{array}$ & $\begin{array}{c}\text { None } \rightarrow++ \\
26 \text { years }\end{array}$ \\
\hline VII & & Sly & $\beta$-D-glucuronidase & HS, DS, KS & $7 q 22$ & $\mathrm{AR}$ & $\begin{array}{c}+/++ \\
15 \text { years }\end{array}$ & ++ & None $\rightarrow++$ \\
\hline IX & & Natowicz & Hyaluronidase & CS & $3 p 21.2-3$ & $\mathrm{AR}$ & unknown & unknown & unknown \\
\hline
\end{tabular}

GAG: glycosaminoglycan, DS: dermatan sulfate, KS: keratan sulphate, CS: chondroitin sulphate, AR: autosomal recessive, XL: X-linked. 
The clinical features of the various mucopolysaccharidoses all result from the intraand extracellular accumulation of glycosaminoglycans. All nine types can result in ocular abnormalities to varying degrees, most commonly corneal opacification, retinopathy, optic nerve abnormalities, and glaucoma. Table 2 summarizes the qualitative likelihood and average age of onset of these abnormalities based on a review of the current literature [74-80]. Based on reported studies, corneal opacification is most commonly seen in type I and type VI [74-80]. Continuous deposition of GAGs within the corneal stroma causes a disruption of the normally highly ordered collagen fibrils, resulting in difficult-to-treat clouding. Chronic corneal edema can lead to neovascularization and permanent scarring of the cornea, resulting in decreased vision. Poor corneal clarity also limits the ability to thoroughly examine intraocular structures such as the lens or retina. The mucopolysaccharidoses were informally categorized into the "severe" and "milder" subtypes. The "severe" subtypes (IH, II, and VII) present early in life with systemic abnormalities including facial dysmorphism and respiratory disease. The "milder" subtypes (IS, II, and IV) have less predictable and milder signs; ophthalmologists are often consulted to check for corneal clouding to aid in the diagnosis [79]. Corneal changes are treated surgically with a full thickness transplant, with some reports suggesting re-opacification in less than one year [76]. Future treatments may include local injection of adenovirus vectors within the cornea in order to reduce the accumulation of GAGs in vivo [72,73,77,79].

Previous reports are disparate regarding which mucopolysaccharidoses carry a risk of glaucoma, although there is consensus that all forms carry some glaucoma risk [71,74-81]. As such, all patients with mucopolysaccharidosis should be screened regularly for an increase in intraocular pressure or changes to the optic nerve. The mucopolysaccharidoses cause a mixed mechanism glaucoma with features of open- and closed-angle forms. There is accumulation of GAGs obstructing an otherwise open-appearing trabecular meshwork and narrowing of the anterior chamber angel from GAG accumulation within adjacent structures. Monitoring these patients is difficult, as corneal opacification limits the view into the anterior chamber and can reduce the accuracy of intraocular pressure measurements. These patients are highly resistant to medical treatment and almost invariably require surgical intervention [78]. GAG deposition within the optic nerve head commonly results in an elevated appearance, easily confused with papilledema from increased intracranial pressure. As these patients continue to live longer, it is possible that the chronic and long-term deposition within the optic nerve head may result in an optic atrophy that can cause further vision loss.

Currently, there are no routine screening protocols in infancy, although trials for type I are underway in several countries [69]. This allows for early diagnosis, frequent monitoring, and timely intervention. Additionally, past treatment for the mucopolysaccharidoses have been quite limited, resulting in a shortened lifespan and severe developmental delay. Recent implementation of bone marrow transplantation and enzyme-replacement therapy has extended the life expectancy for these patients. Because of this, ophthalmologists are just beginning to encounter long-term sequelae of these diseases. Future studies should start to elucidate ideal treatments for these patients.

\subsection{Aniridia}

Congenital aniridia is a rare disorder affecting between 1:40,00 and 1:100,000 births [82-84]. It is named for the partial or total hypoplasia of the iris, but aniridia is known to affect all ocular structures often resulting in corneal scarring, cataracts, glaucoma, and foveal hypoplasia. Visual acuity varies from normal to no light perception, depending on the severity and duration of symptoms.

Aniridia is categorized into sporadic (33\% of cases) and autosomal dominant familial forms ( $66 \%$ of cases). Most forms of aniridia are caused by pathogenic variants affecting $P A X 6$, a highly conserved "master regulator" of eye development, localized to 11 p13 [85-87], with a small fraction of cases remaining unexplained or due to pathogenic variants in ITPR1, FOXC1, or PITX2 [88]. PAX6 contains 14 exons with upstream and down- 
stream regulator regions $[85,89]$. The $P A X 6$ protein is a transcription factor abundantly expressed in neural and ocular tissues, thought to play a crucial role in embryogenesis. Several studies have shown no significant difference in types of pathogenic variants or the severity of disease between these groups [86]. To date, almost 500 unique PAX6 pathogenic variants have been identified (Human PAX6 Pathogenic variant Database, http://1sdb.hgu.mrc.ac.uk/home.php?select_db=PAX6, accessed on 29 July 2021). The majority of the submitted variants involve nonsense or frameshift pathogenic variants resulting in premature termination codons and haploinsufficiency $[85,86]$ and these represent $75-80 \%$ of aniridia cases. Numerous studies have described PAX6 pathogenic variants as resulting in a complete penetrance of aniridic ocular changes; however, single pathogenic variants result in a wide variety and severity of phenotypes [90,91]. Some reports have suggested that the level of disease severity is possibly correlated with the level of PAX6 expression with loss of function pathogenic variants resulting in the most severe cases [86]. Still, this does not explain the varying severity and onset of pathology amongst family members with identical pathogenic variants [90]. Compound heterozygous pathogenic variants in PAX6 are thought to be lethal; however, studies have described such patients with mortality in late gestation or shortly after birth with severe craniofacial and ocular malformations [85]. Of note, pathogenic variants in $11 \mathrm{p} 13$ have also been associated with non-aniridia ocular diagnoses, including microphthalmia, microcornea, coloboma, morning glory optic nerve, and Peters anomaly (discussed earlier). These cases are thought to be caused by missense pathogenic variants, compared with truncating pathogenic variants more frequently resulting in aniridia.

For those with sporadic aniridia, 33\% of patients are diagnosed with WAGR syndrome, a contiguous gene deletion syndrome involving PAX6 and WT1. These two genes are separated by $700 \mathrm{~kb}$ and WAGR is often caused by large deletions or rearrangements [86,92]. Of note, patients with sporadic aniridia require monitoring for the development of a Wilms tumor as part of WAGR syndrome $[85,86]$. Moreover, while less common, patients with pathogenic variants in PAX6 regulatory regions have been described as well. There are cisand trans-regulatory regions that span hundreds of kilobases up and downstream $[85,86]$. Furthermore, various other genes have been described as influencing iris anatomy to various degrees including FOXC1, PITX2, CYP1B1, FOXD3, and TRIM44 [92]. Additionally, a rare cause of aniridia is the Gillespie syndrome, which features partial aniridia, cerebellar ataxia, and intellectual disability, and is caused by recessive pathogenic variants in the ITPR1 gene [93,94].

Clinically, symptoms of aniridia can be categorized into two broad categories: congenital abnormalities and progressive changes, both of which affect vision. Congenital abnormalities including optic nerve hypoplasia and foveal hypoplasia are found in up to $20 \%$ and $90 \%$ of individuals, respectively [86]. These both affect vision at birth and are seen in association with congenital nystagmus, which is indicative of early and often permanent visual impairment. Over time, numerous additional progressive changes are seen as well. A congenital limbal stem cell deficiency results in a progressive keratopathy, resulting in dense corneal opacifications (seen in up to $80 \%$ of patients $[86,95,96]$ ). Cataracts develop in $40-80 \%$ of patients; these lens changes are often seen during childhood but do not become visually significant until young adulthood $[89,97]$. Possibly the most visually devastating effect on patients is glaucomatous damage to the optic nerve. Aniridic glaucoma is a combined open- and closed-angle glaucoma which is often resistant to treatment.

Systemically, patients with sporadic aniridia are at risk of WAGR syndrome, resulting in a Wilms tumor, aniridia, genitourinary abnormalities, and developmental delay. Approximately one third of patients with sporadic aniridia ultimately develop WAGR syndrome due to a contiguous gene deletion syndrome involving both PAX6 and WT1. These patients have a $50 \%$ chance of developing a Wilms tumor and require an abdominal ultrasound to screen for tumor development. Gillespie syndrome, discussed above, makes up less than $2 \%$ of all cases of aniridia and is often associated with atypical ocular findings such as ptosis or corectopia $[85,86,98]$. 
Patients with aniridia need eye care throughout their entire lives. Early intervention is crucial to minimize the effects of amblyopia. Children may require spectacle correction or part-time occlusion. As patients age, multiple surgeries are all but inevitable, including cataract extraction, corneal transplants, and glaucoma surgeries. In one of the largest cohort studies of aniridia to date, trabeculectomy was found to have a $24 \%$ success rate, goniotomy/trabeculotomy were found to have a $33 \%$ success rate, and glaucoma drainage devices were found to have a success rate between 63 and $88 \%$ (manuscript in preparation).

Because of these long-term disease sequelae, the likelihood of visual impairment, and the risk of systemic disease associated with WAGR or Gillespie syndrome, genetic testing is commonly obtained for these patients. Testing usually involves sequencing of PAX6 and WT1, and chromosomal microarray. Sporadic cases of aniridia are typically screened with a renal ultrasound if prior genetic testing is unavailable.

\subsection{Collagen Vascular Disorders}

\subsubsection{Stickler Syndrome}

Stickler syndrome was originally described by Gunnar B. Stickler and his colleagues in 1965 in a select group of patients [99]. Over the subsequent 55 years, genetic testing has uncovered at least five variants of Stickler syndrome, each with unique pathogenic variants and inheritance patters. Two variants (type 1 and type 2 ) are autosomal dominant, resulting on nonsense or frame-shift pathogenic variants of COL2A1 $[100,101]$ or a missense pathogenic variant in COL11A1 [102-105], respectively, and represent 75-90\% of all cases [106]. Another two variants (type 4 and type 5) are autosomal recessive and result in nonsense pathogenic variants of COL9A1 $[107,108]$ and loss-of-function pathogenic variants in COL9A2 [109], respectively, representing $10-20 \%$ of all cases [106].

Clinically, patients with Stickler syndrome have several ocular findings including myopia $[110,111]$, cataracts (wedge shaped, $50 \%$ of patients) [112,113], and retinal detachments (with a two-fold rate of giant retinal tears in at least one eye as compared with other retinal breaks) [114]. These patients also develop glaucoma by several mechanisms. Anatomically, patients can have long iris ciliary processes that cover the trabecular meshwork, thus blocking the aqueous humor outflow from the anterior chamber and leading to intraocular pressure rise [115]. In other families, patients do not have observable anatomical abnormalities but have elevated intraocular pressure with demonstrated glaucomatous progression [116]. Of note, the above clinical characteristics of Stickler syndrome have some overlap with other common systemic syndromes including Marshall syndrome, Wagner syndrome, Weissenbacher syndrome, and Pierre Robin syndrome [101,110,117].

Genetic testing for Stickler syndrome is limited due to the complexity and number of pathogenic variants [101,110]. For most physicians evaluating potential patients, suspicion and evaluation for Stickler syndrome should be increased for the following conditions: neonates present with Pierre Robin syndrome or a midline cleft, infants with myopia/deafness/spondyloepiphyseal dysplasia, families with a history of rhegmatogenous retinal detachments, and sporadic cases of retinal detachments [101]. For treatment, prophylactic laser treatment of the retina has demonstrated a success rate of greater than $75 \%$ for preventing retinal detachments $[118,119]$. There is likely an underreporting of glaucoma due to the paucity of patient reports and studies in the literature [120,121]. However, for the cases that exist, most providers address lowering the pressure with filtration surgery such as goniotomy or a tube shunt. Glaucoma outcomes are typically poor in these patients, and early recognition and prompt management will be critical in the future [122].

\subsubsection{Osteogenesis Imperfecta}

Osteogenesis imperfecta (OI) is a predominantly autosomal dominant ( $90 \%$ of cases) disease affecting type 1 collagen levels or structure [123]. Until very recently, four types of OI were identified with pathogenic variants in COL1A1 or COL1A2 inherited in an autosomal dominant manner [123], with a fifth type reported in patients with a mutated IFITM5 gene [124]. The OI type 1 pathogenic variant results in roughly $50 \%$ less total 
collagen I production by cells, OI type 2 is lethal and results in death in utero, and OI types 3 and 4 have structural abnormalities of the collagen molecules [123]. Systemic findings in most patients with OI include bone fragility, low bone mineral density, skeletal deformities, dentinogenesis imperfecta, hyperlaxity of ligaments, cardiovascular disease, and hearing loss [125-128]. However, type 5 OI has bone fragility, interosseous membrane mineralization, and hyperplastic callus formation [124].

Many ocular symptoms are present in OI (Table 1). For example, corneal thickness is decreased with blue sclera more in OI type 1 [129-134], as well as lower ocular rigidity and shorter axial length $[135,136]$. Retinal detachments are also more frequent in patients with OI type 3 [137-141]. With respect to glaucoma, many patients have undermeasured intraocular pressure due to the altered corneal and scleral biomechanics, which results in patients developing glaucoma with apparently normal pressure measurements [132]. These patients are typically older (adult) and have primary open-angle glaucoma. However, in several cases for children or infants, infantile-onset glaucoma can develop and go unnoticed due to challenges in intraocular pressure measurement [123,142]. Characteristics found in younger patients with infantile-onset glaucoma (or sometimes referred to as primary congenital glaucoma) included buphthalmos, phthisis, corneal opacity, corneal edema, Haab's striae, thin irides and elevated intraocular pressures [142]. Elevated pressure is thought to be due to gonio-trabeculodysgenesis, thus forming suboptimal trabecular meshwork and impairing aqueous humor outflow from the anterior chamber [143].

At present, there is no formal diagnostic criteria or genetic testing used to diagnose OI, let alone the ophthalmic findings to make an immediate OI diagnosis. Much depends on clinical suspicion and general diagnostic testing (e.g., skeletal survey). Treatment for these patients begins with conservative therapy such as aqueous suppressant eye drops, but surgical intervention can include goniotomy, trabeculotomy, trabeculectomy, or tube shunts.

\subsubsection{COL4A1}

In 2015, researchers summarized 21 pathogenic variants in COL4A1 in several families that resulted in abnormally elevated pressures leading to glaucoma [144]. Many pathogenic variants had variable expressivity and intrafamilial variability, but these were inherited in an autosomal dominant fashion. Patients with COL4A1 pathogenic variants present with a variety of cortical abnormalities including cerebrovascular, cardiac, renal, and muscular abnormalities. With respect to the eyes, these patients harbored features similar to AxenfeldRieger syndrome (reviewed earlier), specifically abnormal anterior chamber angles, iris hypoplasia, eccentric pupil, iridocorneal tissue adhesions and aqueous drainage structure abnormalities coupled with elevated intraocular pressure. Because this pathogenic variant discovery is recent and novel, there are few patients to study in order to determine the mechanism driving elevated pressure and likely development of glaucoma. One mouse model study showed that mutant COL4A1 had a dose-dependent impact on anterior segment dysgenesis coupled with abnormally elevated intraocular pressures, thus suggesting basement membrane abnormalities can be driving the phenotype [145]. This is particularly relevant as the trabecular meshwork contains this type of basement membrane, thus hypothetical treatment to prevent development or progression of glaucoma can be addressed with aqueous suppressant medications or trabecular meshwork-modifying surgeries.

\subsubsection{TEK/ANGPT1}

Similar to COL4A1, loss-of-function pathogenic variants in TEK were also recently uncovered in 2016 and have a significant role in Schlemm's canal and trabecular meshwork structure and function [146]. A cohort of 189 families were studied and 10 heterozygous pathogenic variants leading to haploinsufficiency were documented, along with observations of non-penetrance and variable expressivity [146]. Patients with these pathogenic variants were found to have primary congenital glaucoma due to malformation of the aforementioned structures, especially when at least $50 \%$ of TEK signaling was reduced. 
Mouse models have also confirmed these findings [146-148]. Additionally, variants in ANGPT1, a ligand for TEK, also resulted in a similar abnormal Schlemm's canal and trabecular meshwork abnormalities and led to the development of congenital glaucoma [147]. Heterozygous pathogenic variants in ANGPT1 similarly have low penetrance, with two thirds of carriers within families being asymptomatic. This creates both diagnostic and therapeutic challenges in identifying patients that are at high risk of glaucoma and choosing the appropriate treatment based on precise outflow pathway anatomy. Because the drainage pathway is affected, it can be speculated that similar aqueous suppressant medications or trabecular meshwork-modifying surgeries may best address this form of glaucoma. However, if downstream collector channels are affected, then tube shunts or trabeculectomies that bypass the traditional outflow pathways entirely would be more effective.

\subsection{Immunogenetic Disorders Associated with Glaucoma}

Mendelian immunogenetics disorders are a class of monogenic disorders that lead to disease pathology through the disruption of immune pathways and activation of autoimmunity or autoinflammation. Glaucomatous optic neuropathy is a common feature of several of these conditions and two prototypical conditions are Aicardi-Goutieres syndrome (AGS) and Singleton-Merten syndrome (SGMRT).

AGS was first described by Jean Aicardi and Francoise Goutières in 1984 with a case series of eight children from five families with severe early-onset encephalopathy [149]. AGS can be inherited as an autosomal dominant or recessive condition and has significant allelic heterogeneity. AGS is caused by pathogenic variants in genes involved in RNA processing (TREX1, RNASEH2A, RNASEH2B, RNASEH2C, SAMHD1, and ADAR) and innate immunity (IFIH1) (Table 1) [150-152]. In the most severe form, this condition features microcephaly, leukodystrophy, cerebral atrophy, intracranial calcifications, along with hepatosplenomegaly and thrombocytopenia. It is associated with elevated levels of central nervous system type I interferon signaling and often progresses with severe neurologic symptoms and death in early childhood. However, milder forms may show later onset with features of a lupus-like syndrome including painful skin lesions and congenital glaucoma. In a large study on AGS, glaucoma was reported in $6.3 \%$ (23 patients), including $20.8 \%$ (10/48 patients) with SAMHD1 pathogenic variants and no patients with pathogenic variants in ADAR or IFIH1 [153].

Singleton-Merten syndrome (SGMRT) is an autosomal dominant condition first described by Edward B. Singleton and David Merten in 1973 [154]. SGMRT is caused by gainof-function variants in one of two RIG-I-like receptor proteins (DDX58 or IFIH1) [155-157]. These receptors normally recognize exogenous double-stranded RNA and activate innate immune pathways and type I interferon signaling as part of the antiviral response. Systemic features of SGMRT include a psoriasiform skin rash, vascular calcifications, skeletal dysplasia, and dental anomalies. There is variable expressivity, but the prominent ocular feature is juvenile open-angle glaucoma. Glaucoma is the most penetrant feature of SGMRT caused by DDX58 variants, present in 17/18 (94\%) of reported cases [155,158,159]. However, there is both intra-familial and interfamilial variability in the age of onset and severity, with median age of diagnosis at 5 years of age (range 2-18 years of age). IFIH1related SGMRT also features glaucoma in a smaller fraction of cases $(\sim 40 \%)$ and up to $13.5 \%$ of pathogenic variant carriers can be asymptomatic [153]. Additionally, patients with SGMRT may have an elevated rate of corneal transplant failure and have an ocular surface disease [158].

While patients with congenital and juvenile glaucoma secondary to immunogenetic disorders have typically been managed in a similar way as their primary counterparts, the systemic features of AGS have been responsive to immunomodulatory therapy. Specifically, Janus kinase (JAK) inhibitors such as baracitinib hold significant promise in reducing the neurological features of Aicardi-Goutieres, though randomized-controlled trials are needed to substantiate these effects [160]. While these therapies have not been systematically attempted for SGMRT, there is evidence from animal models that they may be also effective 
for this condition [161]. It is unclear whether these immunomodulatory therapies can be useful for the management of glaucoma associated with these conditions and that remains a topic of investigation.

\subsection{Nanophthalmos}

Nanophthalmos is a heritable condition characterized by a small, but structurally normal eye, with resultant high hyperopia. Defining features of nanophthalmos includes a short axial length, variably defined in the literature as less than $20-21 \mathrm{~mm}$, with a proportional decrease in anterior segment dimensions, i.e., corneal diameter and anterior chamber depth [162]. Hyperopia is a strongly heritable genetically with twin studies suggesting that $70-90 \%$ of variance in this disorder is attributable to genetic causes $[163,164]$. Five major genes have been implicated in isolated nanophthalmos, including MFRP, PRSS56, BEST1, TMEM98, CRB1, and MYRF [162,165-169]. For two of these genes (TMEM98, MYRF), the trait is inherited in an autosomal dominant manner, while the remaining genes cause recessive disease (MFRP, PRSS56, BEST1, CRB1). Additionally, several genes have been associated with nanophthalmos as part of a multisystem syndrome, including MYRF and FAM111A [168,170]. Variants in MYRF, which underlies the NNO1 locus [168,171], have been identified an emerging syndrome featuring a congenital diaphragmatic hernia, cardiac and pulmonary vascular anomalies, urogenital anomalies, and nanophthalmos $[168,172,173]$. Kenny-Caffey syndrome is a rare autosomal dominant syndrome caused by pathogenic variants in FAM111A and featuring skeletal dysplasia, short-stature, and microorchidism in males $[170,174,175]$. Cohort studies of nanophthalmos have had a widely variable diagnostic yield of genetic testing between 19 and 90\% [176-178]. This is likely related to founder effects, patient population selection, and differences among ethnic groups. Defining the genetic etiology is important for patient counseling and management as different genetic causes are associated with varying ocular and systemic features.

Though the defining feature of nanophthalmos is short axial length, nanophthalmos is frequently associated with ocular complications, presenting as high hyperopia with amblyopia and partially accommodative esotropia in early childhood (Table 1) [162]. Given the anterior segment structure, patients are predisposed to angle closure and the resulting angle closure glaucoma, and often need cataract surgery early in life. Vision loss may also result from other associated retinal findings, including foveal hypoplasia, optic disc drusen, retinoschisis and foveoschisis, retinitis pigmentosa, chorioretinal folds, or central retinal vein occlusions, or complications from ocular surgery [162,179]. MFRP, CRB1, and BEST1 genes have also been variably associated with other ocular features including retinal degeneration, optic disc drusen, and macular dystrophy [180-182]. Many genes associated with Leber congenital amaurosis in addition to $C R B 1$ are also associated with high hyperopia and short axial length [183-185].

Glaucoma and other ocular complications secondary to nanophthalmos may be difficult to manage and genetic diagnosis can be helpful for early recognition. For example, in patients with cardiac-urogenital syndrome and MYRF loss-of-function variants, an early screen for refractive error and amblyopia is critical to prevent irreversible vision loss. Angle closure in nanophthalmos patients is primarily managed by lens extraction, but complications can occur in up to $40-60 \%$ of cases $[179,186,187]$. Intraoperative and postoperative risks include increased rates of corneal endothelial damage, capsular rupture and vitreous loss, intraoperative aqueous misdirection, uveal effusion syndrome, and cystoid macular edema. Prophylactic scleral windows may reduce the rate of complication, owing to a thickened sclera and choroid that may predispose these conditions. While genetic therapies for nanophthalmos have not yet reached the clinical realm, there is some promise for gene replacement strategies for MFRP based on animal models [188].

\section{Conclusions}

Childhood glaucoma has many associations with systemic syndromes that have grounding in key regulatory genes. While some types of childhood glaucoma, such as ARS 
or aniridia, have hundreds of known pathogenic variants in a single gene, others, such as nanophthalmos and collagen-vascular disorders, have significant genetic heterogeneity. Diagnostic yield from genetic testing thus varies widely for each of the conditions. However, many of the specific constellations of ocular and systemic signs and symptoms may point to a specific genetic diagnosis in the hands of an astute clinician. Furthermore, recognition of these syndromes is critical for early diagnosis and treatment of glaucoma associated with these disorders. It is fortunate that many of these syndromes yield consistent clinical findings, as it would otherwise be difficult to detect elevated intraocular pressure or glaucoma in children given difficulty in communication and clinical testing. These consistent features can be attributed to the fact that the regulatory genes that are commonly affected in childhood glaucoma ultimately play a role in other developmental processes and cause perturbations in other organ systems. Even more, while rarer forms of childhood glaucoma have more severe and obvious deficits, their underpinnings may shed light on the possible mechanisms driving other forms of glaucoma (e.g., adult-onset glaucoma) with subtle side effects. Genetic testing plays a critical role in confirming clinical diagnostic suspicions and will become more important as gene/disease specific treatments are developed for childhood glaucoma.

Fortunately, the ability to create targeted biopharmaceutics to address these pathogenic variants are coming within reach due to the advent of high-throughput technologies such as single-cell RNA sequencing, whole genome sequencing with small sample inputs, CRISPR/Cas9 gene editing technology, compound library drug screening, and large scale hybridoma antibody synthesis. The dramatic drop in the cost of these technologies and high-fidelity of their performance can herald a new era of expedited diagnoses of childhood glaucoma coupled with possible treatments that mitigate or slow the rate of vision loss. Furthermore, specific rare syndromes can shed light on common biological mechanisms of glaucoma and novel pathways to explore for therapeutics, including bypassing specific structural defects and immunomodulatory therapy. However, the limited study population of patients and families with childhood glaucoma presents a challenge for therapeutic trials. For many of the above subtypes of childhood glaucoma, the description was completely dependent on the findings multi-generational families with highly penetrant variants of syndrome-associated glaucoma. Unfortunately, without more study subjects that have clear inheritance and pathogenic variant patterns and better descriptions of natural history and outcomes, it will remain difficult to expeditiously advance future diagnostics and therapeutics. Our review highlights the value that studying these rare disorders can bring towards patient diagnosis, treatment, and providing insights into more common forms of glaucoma.

Author Contributions: Conceptualization, methodology, writing —original draft preparation, writing review and editing D.A.B., A.J., L.P.; supervision, L.P.; funding acquisition, L.P. All authors have read and agreed to the published version of the manuscript.

Funding: LP was supported by the National Eye Institute K08 grant [EY032098] and the Glaucoma Research Foundation.

Data Availability Statement: All relevant data are included in the manuscript text and figures.

Conflicts of Interest: The authors have no relevant conflict of interests.

\section{References}

1. Weinreb, R.N.; Leung, C.K.; Crowston, J.G.; Medeiros, F.A.; Friedman, D.S.; Wiggs, J.L.; Martin, K.R. Primary open-angle glaucoma. Nat. Rev. Dis. Primers 2016, 2, 16067. [CrossRef]

2. World Health Organization. Blindness and Vision Impairment. Available online: https://www.who.int/news-room/fact-sheets/ detail/blindness-and-visual-impairment (accessed on 25 July 2021).

3. Allison, K.; Patel, D.; Alabi, O. Epidemiology of Glaucoma: The Past, Present, and Predictions for the Future. Cureus 2020, 12, e11686. [CrossRef] 
4. $\quad$ Da Soh, Z.; Yu, M.; Betzler, B.K.; Majithia, S.; Thakur, S.; Tham, Y.C.; Wong, T.Y.; Aung, T.; Friedman, D.S.; Cheng, C.Y. The Global Extent of Undetected Glaucoma in Adults: A Systematic Review and Meta-analysis. Ophthalmology 2021. Online ahead of print. [CrossRef]

5. Macdonald, A.E. Causes of Blindness in Canada: An Analysis of 24,605 Cases Registered with the Canadian National Institute for the Blind. Can. Med. Assoc. J. 1965, 92, 264-279. [PubMed]

6. Midha, N.; Sidhu, T.; Chaturvedi, N.; Sinha, R.; Shende, D.R.; Dada, T.; Gupta, V.; Sihota, R. Systemic Associations of Childhood Glaucoma: A Review. J. Pediatric Ophthalmol. Strabismus 2018, 55, 397-402. [CrossRef]

7. Papadopoulos, M.; Cable, N.; Rahi, J.; Khaw, P.T.; BIG Eye Study Investigators. The British Infantile and Childhood Glaucoma (BIG) Eye Study. Investig. Ophthalmol. Vis. Sci. 2007, 48, 4100-4106. [CrossRef]

8. Aponte, E.P.; Diehl, N.; Mohney, B.G. Incidence and clinical characteristics of childhood glaucoma: A population-based study. Arch. Ophthalmol. 2010, 128, 478-482. [CrossRef] [PubMed]

9. Badawi, A.H.; Al-Muhaylib, A.A.; Al Owaifeer, A.M.; Al-Essa, R.S.; Al-Shahwan, S.A. Primary congenital glaucoma: An updated review. Saudi J. Ophthalmol. 2019, 33, 382-388. [CrossRef] [PubMed]

10. Rieger, H. Verlagerung und Schlitzform der Pupille mit Hypoplasie des Irisvorderblattes. Z. Augenheilkd 1934, 84, 98-99.

11. Axenfeld, T. Embryotoxon cornae posterius. Ber. Deutsch. Ophthalmol. Ges. 1920, 42, 301-302.

12. Nishimura, D.Y.; Swiderski, R.E.; Alward, W.L.; Searby, C.C.; Patil, S.R.; Bennet, S.R.; Kanis, A.B.; Gastier, J.M.; Stone, E.M.; Sheffield, V.C. The forkhead transcription factor gene FKHL7 is responsible for glaucoma phenotypes which map to 6p25. Nat. Genet. 1998, 19, 140-147. [CrossRef]

13. Mears, A.J.; Jordan, T.; Mirzayans, F.; Dubois, S.; Kume, T.; Parlee, M.; Ritch, R.; Koop, B.; Kuo, W.L.; Collins, C.; et al. Mutations of the forkhead/winged-helix gene, FKHL7, in patients with Axenfeld-Rieger anomaly. Am. J. Hum. Genet. 1998, 63, $1316-1328$. [CrossRef]

14. Semina, E.V.; Reiter, R.; Leysens, N.J.; Alward, W.L.; Small, K.W.; Datson, N.A.; Siegel-Bartelt, J.; Bierke-Nelson, D.; Bitoun, P.; Zabel, B.U.; et al. Cloning and characterization of a novel bicoid-related homeobox transcription factor gene, RIEG, involved in Rieger syndrome. Nat. Genet. 1996, 14, 392-399. [CrossRef] [PubMed]

15. Reis, L.M.; Tyler, R.C.; Volkmann Kloss, B.A.; Schilter, K.F.; Levin, A.V.; Lowry, R.B.; Zwijnenburg, P.J.; Stroh, E.; Broeckel, U.; Murray, J.C.; et al. PITX2 and FOXC1 spectrum of mutations in ocular syndromes. Eur. J. Hum. Genet. 2012, 20, 1224-1233. [CrossRef] [PubMed]

16. Cox, C.J.; Espinoza, H.M.; McWilliams, B.; Chappell, K.; Morton, L.; Hjalt, T.A.; Semina, E.V.; Amendt, B.A. Differential regulation of gene expression by PITX2 isoforms. J. Biol. Chem. 2002, 277, 25001-25010. [CrossRef] [PubMed]

17. Kaufmann, E.; Knochel, W. Five years on the wings of fork head. Mech. Dev. 1996, 57, 3-20. [CrossRef]

18. Lehmann, O.J.; Sowden, J.C.; Carlsson, P.; Jordan, T.; Bhattacharya, S.S. Fox's in development and disease. Trends Genet. 2003, 19, 339-344. [CrossRef]

19. Seifi, M.; Walter, M.A. Accurate prediction of functional, structural, and stability changes in PITX2 mutations using in silico bioinformatics algorithms. PLoS ONE 2018, 13, e0195971. [CrossRef] [PubMed]

20. Schinzel, A.; Brecevic, L.; Dutly, F.; Baumer, A.; Binkert, F.; Largo, R.H. Multiple congenital anomalies including the Rieger eye malformation in a boy with interstitial deletion of (4) (q25->q27) secondary to a balanced insertion in his normal father: Evidence for haplotype insufficiency causing the Rieger malformation. J. Med. Genet. 1997, 34, 1012-1014. [CrossRef] [PubMed]

21. Flomen, R.H.; Gorman, P.A.; Vatcheva, R.; Groet, J.; Barisic, I.; Ligutic, I.; Sheer, D.; Nizetic, D. Rieger syndrome locus: A new reciprocal translocation $\mathrm{t}(4 ; 12)(\mathrm{q} 25 ; \mathrm{q} 15)$ and a deletion $\operatorname{del}(4)(\mathrm{q} 25 \mathrm{q} 27)$ both break between markers D4S2945 and D4S193. J. Med. Genet. 1997, 34, 191-195. [CrossRef]

22. Footz, T.; Idrees, F.; Acharya, M.; Kozlowski, K.; Walter, M.A. Analysis of mutations of the PITX2 transcription factor found in patients with Axenfeld-Rieger syndrome. Investig. Ophthalmol. Vis. Sci. 2009, 50, 2599-2606. [CrossRef]

23. Kozlowski, K.; Walter, M.A. Variation in residual PITX2 activity underlies the phenotypic spectrum of anterior segment developmental disorders. Hum. Mol. Genet. 2000, 9, 2131-2139. [CrossRef]

24. Berry, F.B.; Lines, M.A.; Oas, J.M.; Footz, T.; Underhill, D.A.; Gage, P.J.; Walter, M.A. Functional interactions between FOXC1 and PITX2 underlie the sensitivity to FOXC1 gene dose in Axenfeld-Rieger syndrome and anterior segment dysgenesis. Hum. Mol. Genet. 2006, 15, 905-919. [CrossRef]

25. Reis, L.M.; Semina, E.V. Genetics of anterior segment dysgenesis disorders. Curr. Opin. Ophthalmol. 2011, 22, 314-324. [CrossRef]

26. Shields, M.B. Axenfeld-Rieger syndrome: A theory of mechanism and distinctions from the iridocorneal endothelial syndrome. Trans. Am. Ophthalmol. Soc. 1983, 81, 736-784. [PubMed]

27. Strungaru, M.H.; Dinu, I.; Walter, M.A. Genotype-phenotype correlations in Axenfeld-Rieger malformation and glaucoma patients with FOXC1 and PITX2 mutations. Investig. Ophthalmol. Vis. Sci. 2007, 48, 228-237. [CrossRef]

28. Souzeau, E.; Siggs, O.M.; Zhou, T.; Galanopoulos, A.; Hodson, T.; Taranath, D.; Mills, R.A.; Landers, J.; Pater, J.; Smith, J.E.; et al. Glaucoma spectrum and age-related prevalence of individuals with FOXC1 and PITX2 variants. Eur. J. Hum. Genet. 2017, 25, 1290. [CrossRef]

29. Berg, F. Erbliches Jugendliches Glaukom. Acta Ophthalmol. 1932, 10, 568-587. [CrossRef]

30. Alward, W.L.; Semina, E.V.; Kalenak, J.W.; Heon, E.; Sheth, B.P.; Stone, E.M.; Murray, J.C. Autosomal dominant iris hypoplasia is caused by a mutation in the Rieger syndrome (RIEG/PITX2) gene. Am. J. Ophthalmol. 1998, 125, 98-100. [CrossRef] 
31. Shields, M.B.; Buckley, E.; Klintworth, G.K.; Thresher, R. Axenfeld-Rieger syndrome. A spectrum of developmental disorders. Surv. Ophthalmol. 1985, 29, 387-409. [CrossRef]

32. Jorgenson, R.J.; Levin, L.S.; Cross, H.E.; Yoder, F.; Kelly, T.E. The Rieger syndrome. Am. J. Med. Genet. 1978, 2, 307-318. [CrossRef] [PubMed]

33. Gould, D.B.; John, S.W. Anterior segment dysgenesis and the developmental glaucomas are complex traits. Hum. Mol. Genet. 2002, 11, 1185-1193. [CrossRef]

34. Kleinmann, R.E.; Kazarian, E.L.; Raptopoulos, V.; Braverman, L.E. Primary empty sella and Rieger's anomaly of the anterior chamber of the eye: A familial syndrome. N. Engl. J. Med. 1981, 304, 90-93. [CrossRef] [PubMed]

35. Brodsky, M.C.; Whiteside-Michel, J.; Merin, L.M. Rieger anomaly and congenital glaucoma in the SHORT syndrome. Arch. Ophthalmol. 1996, 114, 1146-1147. [CrossRef]

36. Brooks, J.K.; Coccaro, P.J., Jr.; Zarbin, M.A. The Rieger anomaly concomitant with multiple dental, craniofacial, and somatic midline anomalies and short stature. Oral Surg. Oral Med. Oral Pathol. 1989, 68, 717-724. [CrossRef]

37. Tsai, J.C.; Grajewski, A.L. Cardiac valvular disease and Axenfeld-Rieger syndrome. Am. J. Ophthalmol. 1994, 118, 255-256. [CrossRef]

38. Cunningham, E.T., Jr.; Eliott, D.; Miller, N.R.; Maumenee, I.H.; Green, W.R. Familial Axenfeld-Rieger anomaly, atrial septal defect, and sensorineural hearing loss: A possible new genetic syndrome. Arch. Ophthalmol. 1998, 116, 78-82. [CrossRef] [PubMed]

39. Busch, G.; Weiskopf, J.; Busch, K.T. Dysgenesis mesodermalis et ectodermalis Rieger or Rieger's disease. Klin. Mon. Augenheilkd. Augenarztl. Fortbild. 1960, 136, 512-523.

40. Gauthier, A.C.; Wiggs, J.L. Childhood glaucoma genes and phenotypes: Focus on FOXC1 mutations causing anterior segment dysgenesis and hearing loss. Exp. Eye Res. 2020, 190, 107893. [CrossRef] [PubMed]

41. Seifi, M.; Walter, M.A. Axenfeld-Rieger syndrome. Clin. Genet. 2018, 93, 1123-1130. [CrossRef]

42. D'Haene, B.; Meire, F.; Claerhout, I.; Kroes, H.Y.; Plomp, A.; Arens, Y.H.; de Ravel, T.; Casteels, I.; De Jaegere, S.; Hooghe, S.; et al. Expanding the spectrum of FOXC1 and PITX2 mutations and copy number changes in patients with anterior segment malformations. Invest. Ophthalmol. Vis. Sci. 2011, 52, 324-333. [CrossRef]

43. Chrystal, P.W.; Walter, M.A. Aniridia and Axenfeld-Rieger Syndrome: Clinical presentations, molecular genetics and current/emerging therapies. Exp. Eye Res. 2019, 189, 107815. [CrossRef] [PubMed]

44. Ma, A.S.; Grigg, J.R.; Jamieson, R.V. Phenotype-genotype correlations and emerging pathways in ocular anterior segment dysgenesis. Hum. Genet. 2019, 138, 899-915. [CrossRef] [PubMed]

45. Jordan, T.; Hanson, I.; Zaletayev, D.; Hodgson, S.; Prosser, J.; Seawright, A.; Hastie, N.; van Heyningen, V. The human PAX6 gene is mutated in two patients with aniridia. Nat. Genet. 1992, 1, 328-332. [CrossRef] [PubMed]

46. Ton, C.C.; Hirvonen, H.; Miwa, H.; Weil, M.M.; Monaghan, P.; Jordan, T.; van Heyningen, V.; Hastie, N.D.; Meijers-Heijboer, H.; Drechsler, M.; et al. Positional cloning and characterization of a paired box- and homeobox-containing gene from the aniridia region. Cell 1991, 67, 1059-1074. [CrossRef]

47. Stoilov, I.; Akarsu, A.N.; Sarfarazi, M. Identification of three different truncating mutations in cytochrome P4501B1 (CYP1B1) as the principal cause of primary congenital glaucoma (Buphthalmos) in families linked to the GLC3A locus on chromosome 2p21. Hum. Mol. Genet. 1997, 6, 641-647. [CrossRef]

48. Lesnik Oberstein, S.A.; Kriek, M.; White, S.J.; Kalf, M.E.; Szuhai, K.; den Dunnen, J.T.; Breuning, M.H.; Hennekam, R.C. Peters Plus syndrome is caused by mutations in B3GALTL, a putative glycosyltransferase. Am. J. Hum. Genet. 2006, 79, 562-566. [CrossRef] [PubMed]

49. Hanson, I.M.; Fletcher, J.M.; Jordan, T.; Brown, A.; Taylor, D.; Adams, R.J.; Punnett, H.H.; van Heyningen, V. Mutations at the PAX6 locus are found in heterogeneous anterior segment malformations including Peters' anomaly. Nat. Genet. 1994, 6, 168-173. [CrossRef] [PubMed]

50. Waring, G.O., 3rd; Rodrigues, M.M.; Laibson, P.R. Anterior chamber cleavage syndrome. A stepladder classification. Surv. Ophthalmol. 1975, 20, 3-27. [CrossRef]

51. Matsubara, A.; Ozeki, H.; Matsunaga, N.; Nozaki, M.; Ashikari, M.; Shirai, S.; Ogura, Y. Histopathological examination of two cases of anterior staphyloma associated with Peters' anomaly and persistent hyperplastic primary vitreous. Br. J. Ophthalmol. 2001, 85, 1421-1425. [CrossRef] [PubMed]

52. Townsend, W.M. Congenital Corneal Leukomas. Am. J. Ophthalmol. 1974, 77, 80-86. [CrossRef]

53. van Schooneveld, M.J.; Delleman, J.W.; Beemer, F.A.; Bleeker-Wagemakers, E.M. Peters'-plus: A new syndrome. Ophthalmic Paediatr. Genet. 1984, 4, 141-145. [CrossRef] [PubMed]

54. Kresca, L.J.; Goldberg, M.F. Peters' anomaly: Dominant inheritance in one pedigree and dextrocardia in another. J. Pediatr. Ophthalmol. Strabismus 1978, 15, 141-146. [CrossRef] [PubMed]

55. Ginsberg, J.; Buchino, J.J.; Menefee, M.; Ballard, E.; Husain, I. Multiple congenital ocular anomalies with bilateral agenesis of the urinary tract. Ann. Ophthalmol. 1979, 11, 1021-1029.

56. Frydman, M.; Weinstock, A.L.; Cohen, H.A.; Savir, H.; Varsano, I. Autosomal recessive Peters anomaly, typical facial appearance, failure to thrive, hydrocephalus, and other anomalies: Further delineation of the Krause-Kivlin syndrome. Am. J. Med. Genet. 1991, 40, 34-40. [CrossRef] [PubMed] 
57. de Almeida, J.C.; Reis, D.F.; Llerena Junior, J.; Barbosa Neto, J.; Pontes, R.L.; Middleton, S.; Telles, L.F. Short stature, brachydactyly, and Peters' anomaly (Peters'-plus syndrome): Confirmation of autosomal recessive inheritance. J. Med. Genet. 1991, 28, 277-279. [CrossRef]

58. Dolezal, K.A.; Besirli, C.G.; Mian, S.I.; Sugar, A.; Moroi, S.E.; Bohnsack, B.L. Glaucoma and Cornea Surgery Outcomes in Peters Anomaly. Am. J. Ophthalmol. 2019, 208, 367-375. [CrossRef]

59. Sheheitli, H.; Groth, S.L.; Chang, T.C.P.; Hodapp, E.A.; Grajewski, A.L. A Novel Surgical Approach in the Management of Peters Anomaly With Glaucoma. J. Pediatr. Ophthalmol. Strabismus 2020, 57, e25-e29. [CrossRef] [PubMed]

60. Cheong, S.S.; Hentschel, L.; Davidson, A.E.; Gerrelli, D.; Davie, R.; Rizzo, R.; Pontikos, N.; Plagnol, V.; Moore, A.T.; Sowden, J.C.; et al. Mutations in CPAMD8 Cause a Unique Form of Autosomal-Recessive Anterior Segment Dysgenesis. Am. J. Hum. Genet. 2016, 99, 1338-1352. [CrossRef] [PubMed]

61. Janssen, S.F.; Gorgels, T.G.; Ten Brink, J.B.; Jansonius, N.M.; Bergen, A.A. Gene expression-based comparison of the human secretory neuroepithelia of the brain choroid plexus and the ocular ciliary body: Potential implications for glaucoma. Fluids Barriers CNS 2014, 11, 2. [CrossRef]

62. Chen, Y.; Huang, K.; Nakatsu, M.N.; Xue, Z.; Deng, S.X.; Fan, G. Identification of novel molecular markers through transcriptomic analysis in human fetal and adult corneal endothelial cells. Hum. Mol. Genet. 2013, 22, 1271-1279. [CrossRef]

63. Li, X.; Sun, W.; Xiao, X.; Fang, L.; Li, S.; Liu, X.; Zhang, Q. Biallelic variants in CPAMD8 are associated with primary open-angle glaucoma and primary angle-closure glaucoma. Br. J. Ophthalmol. 2021. [CrossRef]

64. Siggs, O.M.; Souzeau, E.; Taranath, D.A.; Dubowsky, A.; Chappell, A.; Zhou, T.; Javadiyan, S.; Nicholl, J.; Kearns, L.S.; Staffieri, S.E.; et al. Biallelic CPAMD8 Variants Are a Frequent Cause of Childhood and Juvenile Open-Angle Glaucoma. Ophthalmology 2020, 127, 758-766. [CrossRef]

65. Bonet-Fernandez, J.M.; Aroca-Aguilar, J.D.; Corton, M.; Ramirez, A.I.; Alexandre-Moreno, S.; Garcia-Anton, M.T.; Salazar, J.J.; Ferre-Fernandez, J.J.; Atienzar-Aroca, R.; Villaverde, C.; et al. CPAMD8 loss-of-function underlies non-dominant congenital glaucoma with variable anterior segment dysgenesis and abnormal extracellular matrix. Hum. Genet. 2020, 139, $1209-1231$. [CrossRef]

66. Zanetti, A.; D’Avanzo, F.; Rigon, L.; Rampazzo, A.; Concolino, D.; Barone, R.; Volpi, N.; Santoro, L.; Lualdi, S.; Bertola, F.; et al. Molecular diagnosis of patients affected by mucopolysaccharidosis: A multicenter study. Eur. J. Pediatr. 2019, 178, 739-753. [CrossRef]

67. Stapleton, M.; Hoshina, H.; Sawamoto, K.; Kubaski, F.; Mason, R.W.; Mackenzie, W.G.; Theroux, M.; Kobayashi, H.; Yamaguchi, S.; Suzuki, Y.; et al. Critical review of current MPS guidelines and management. Mol. Genet. Metab. 2019, 126, 238-245. [CrossRef] [PubMed]

68. Sawamoto, K.; Alvarez Gonzalez, J.V.; Piechnik, M.; Otero, F.J.; Couce, M.L.; Suzuki, Y.; Tomatsu, S. Mucopolysaccharidosis IVA: Diagnosis, Treatment, and Management. Int. J. Mol. Sci. 2020, 21, 1517. [CrossRef] [PubMed]

69. Parini, R.; Biondi, A. The new frame for Mucopolysaccharidoses. Ital. J. Pediatr. 2018, 44, 117. [CrossRef] [PubMed]

70. Khan, S.A.; Peracha, H.; Ballhausen, D.; Wiesbauer, A.; Rohrbach, M.; Gautschi, M.; Mason, R.W.; Giugliani, R.; Suzuki, Y.; Orii, K.E.; et al. Epidemiology of mucopolysaccharidoses. Mol. Genet. Metab. 2017, 121, 227-240. [CrossRef]

71. Zhang, J.R.; Wang, J.H.; Lin, H.Z.; Lee, Y.C. Anterior Chamber Angles in Different Types of Mucopolysaccharidoses. Am. J. Ophthalmol. 2020, 212, 175-184. [CrossRef]

72. Kobayashi, H. Recent trends in mucopolysaccharidosis research. J. Hum. Genet. 2019, 64, 127-137. [CrossRef]

73. McBride, K.L.; Flanigan, K.M. Update in the Mucopolysaccharidoses. Semin. Pediatr. Neurol. 2021, 37, 100874. [CrossRef]

74. Tomatsu, S.; Pitz, S.; Hampel, U. Ophthalmological Findings in Mucopolysaccharidoses. J. Clin. Med. 2019, 8, 1467. [CrossRef]

75. Ferrari, S.; Ponzin, D.; Ashworth, J.L.; Fahnehjelm, K.T.; Summers, C.G.; Harmatz, P.R.; Scarpa, M. Diagnosis and management of ophthalmological features in patients with mucopolysaccharidosis. Br. J. Ophthalmol. 2011, 95, 613-619. [CrossRef]

76. Fenzl, C.R.; Teramoto, K.; Moshirfar, M. Ocular manifestations and management recommendations of lysosomal storage disorders I: Mucopolysaccharidoses. Clin. Ophthalmol. 2015, 9, 1633-1644. [CrossRef]

77. Del Longo, A.; Piozzi, E.; Schweizer, F. Ocular features in mucopolysaccharidosis: Diagnosis and treatment. Ital. J. Pediatr. 2018, 44, 125. [CrossRef]

78. Bruscolini, A.; Amorelli, G.M.; Rama, P.; Lambiase, A.; La Cava, M.; Abbouda, A. Involvement of the Anterior Segment of the Eye in Patients with Mucopolysaccharidoses: A Review of Reported Cases and Updates on the Latest Diagnostic Instrumentation. Semin. Ophthalmol. 2017, 32, 707-714. [CrossRef] [PubMed]

79. Ashworth, J.L.; Biswas, S.; Wraith, E.; Lloyd, I.C. Mucopolysaccharidoses and the eye. Surv. Ophthalmol. 2006, 51, 1-17. [CrossRef]

80. Ashworth, J.L.; Biswas, S.; Wraith, E.; Lloyd, I.C. The ocular features of the mucopolysaccharidoses. Eye (London) 2006, 20, 553-563. [CrossRef] [PubMed]

81. Summers, C.G.; Ashworth, J.L. Ocular manifestations as key features for diagnosing mucopolysaccharidoses. Rheumatology (Oxford) 2011, 50 (Suppl. 5), v34-v40. [CrossRef] [PubMed]

82. Eden, U.; Iggman, D.; Riise, R.; Tornqvist, K. Epidemiology of aniridia in Sweden and Norway. Acta Ophthalmol. 2008, 86, 727-729. [CrossRef]

83. Eden, U.; Beijar, C.; Riise, R.; Tornqvist, K. Aniridia among children and teenagers in Sweden and Norway. Acta Ophthalmol. 2008, 86, 730-734. [CrossRef] 
84. Nelson, L.B.; Spaeth, G.L.; Nowinski, T.S.; Margo, C.E.; Jackson, L. Aniridia. A review. Surv. Ophthalmol. 1984, $28,621-642$. [CrossRef]

85. Wawrocka, A.; Krawczynski, M.R. The genetics of aniridia-simple things become complicated. J. Appl. Genet. 2018, 59, 151-159. [CrossRef]

86. Lee, H.J.; Colby, K.A. A review of the clinical and genetic aspects of aniridia. Semin. Ophthalmol. 2013, 28, 306-312. [CrossRef] [PubMed]

87. Glaser, T.; Walton, D.S.; Maas, R.L. Genomic structure, evolutionary conservation and aniridia mutations in the human PAX6 gene. Nat. Genet. 1992, 2, 232-239. [CrossRef]

88. Hall, H.N.; Williamson, K.A.; FitzPatrick, D.R. The genetic architecture of aniridia and Gillespie syndrome. Hum. Genet. 2019, 138, 881-898. [CrossRef] [PubMed]

89. Wang, J.D.; Zhang, J.S.; Xiong, Y.; Li, J.; Li, X.X.; Liu, X.; Zhao, J.; Tsai, F.F.; Vishal, J.; You, Q.S.; et al. Congenital aniridia with cataract: Case series. BMC Ophthalmol. 2017, 17, 115. [CrossRef]

90. Wang, G.M.; Prasov, L.; Al-Hasani, H.; Marrs, C.E.R.; Tolia, S.; Wiinikka-Buesser, L.; Richards, J.E.; Bohnsack, B.L. Phenotypic Variation in a Four-Generation Family with Aniridia Carrying a Novel PAX6 Mutation. J. Ophthalmol. 2018, 2018, 5978293. [CrossRef]

91. Parsa, K.K.; Javaheri, M.; Song, J.C.; Borchert, M. Congenital Aniridia: A Descriptive Case Report of Six Family Members Showing Multiple Phenotypes of the Same Disease with Genetic Analysis of the PAX-6 Gene. Invest. Ophthalmol. Vis. Sci. 2003, $44,1267$.

92. Samant, M.; Chauhan, B.K.; Lathrop, K.L.; Nischal, K.K. Congenital aniridia: Etiology, manifestations and management. Expert Rev. Ophthalmol. 2016, 11, 135-144. [CrossRef] [PubMed]

93. McEntagart, M.; Williamson, K.A.; Rainger, J.K.; Wheeler, A.; Seawright, A.; De Baere, E.; Verdin, H.; Bergendahl, L.T.; Quigley, A.; Rainger, J.; et al. A Restricted Repertoire of De Novo Mutations in ITPR1 Cause Gillespie Syndrome with Evidence for Dominant-Negative Effect. Am. J. Hum. Genet. 2016, 98, 981-992. [CrossRef]

94. Gerber, S.; Alzayady, K.J.; Burglen, L.; Bremond-Gignac, D.; Marchesin, V.; Roche, O.; Rio, M.; Funalot, B.; Calmon, R.; Durr, A.; et al. Recessive and Dominant De Novo ITPR1 Mutations Cause Gillespie Syndrome. Am. J. Hum. Genet. 2016, 98, 971-980. [CrossRef] [PubMed]

95. Yazdanpanah, G.; Bohm, K.J.; Hassan, O.M.; Karas, F.I.; Elhusseiny, A.M.; Nonpassopon, M.; Niparugs, M.; Tu, E.Y.; Sugar, J.; Rosenblatt, M.I.; et al. Management of Congenital Aniridia-Associated Keratopathy: Long-Term Outcomes from a Tertiary Referral Center. Am. J. Ophthalmol. 2020, 210, 8-18. [CrossRef]

96. Lee, H.; Khan, R.; O'Keefe, M. Aniridia: Current pathology and management. Acta Ophthalmol. 2008, 86, 708-715. [CrossRef] [PubMed]

97. Neuhann, I.M.; Neuhann, T.F. Cataract surgery and aniridia. Curr. Opin. Ophthalmol. 2010, 21, 60-64. [CrossRef] [PubMed]

98. Hingorani, M.; Hanson, I.; van Heyningen, V. Aniridia. Eur. J. Hum. Genet. 2012, 20, 1011-1017. [CrossRef]

99. Stickler, G.B.; Belau, P.G.; Farrell, F.J.; Jones, J.D.; Pugh, D.G.; Steinberg, A.G.; Ward, L.E. Hereditary Progressive ArthroOphthalmopathy. Mayo Clin. Proc. 1965, 40, 433-455.

100. Francomano, C.A.; Liberfarb, R.M.; Hirose, T.; Maumenee, I.H.; Streeten, E.A.; Meyers, D.A.; Pyeritz, R.E. The Stickler syndrome: Evidence for close linkage to the structural gene for type II collagen. Genomics 1987, 1, 293-296. [CrossRef]

101. Snead, M.P.; Yates, J.R. Clinical and Molecular genetics of Stickler syndrome. J. Med. Genet. 1999, 36, $353-359$.

102. Luo, Y.Y.; Szlarski, P.M.; Kehlet, S.N.; Karsdal, M.A. Chapter 11-Type XI collagen. In Biochemistry of Collagens, Laminins and Elastin, 3th ed.; Karsdal, M.A., Ed.; Academic Press: Cambridge, MA, USA, 2019; pp. 99-106.

103. Martin, S.; Richards, A.J.; Yates, J.R.; Scott, J.D.; Pope, M.; Snead, M.P. Stickler syndrome: Further mutations in COL11A1 and evidence for additional locus heterogeneity. Eur. J. Hum. Genet. 1999, 7, 807-814. [CrossRef]

104. Acke, F.R.; Malfait, F.; Vanakker, O.M.; Steyaert, W.; De Leeneer, K.; Mortier, G.; Dhooge, I.; De Paepe, A.; De Leenheer, E.M.; Coucke, P.J. Novel pathogenic COL11A1/COL11A2 variants in Stickler syndrome detected by targeted NGS and exome sequencing. Mol. Genet. Metab. 2014, 113, 230-235. [CrossRef]

105. Rose, P.S.; Ahn, N.U.; Levy, H.P.; Magid, D.; Davis, J.; Liberfarb, R.M.; Sponseller, P.D.; Francomano, C.A. The hip in Stickler syndrome. J. Pediatr. Orthop. 2001, 21, 657-663. [CrossRef]

106. Snead, M.P.; McNinch, A.M.; Poulson, A.V.; Bearcroft, P.; Silverman, B.; Gomersall, P.; Parfect, V.; Richards, A.J. Stickler syndrome, ocular-only variants and a key diagnostic role for the ophthalmologist. Eye (London) 2011, 25, 1389-1400. [CrossRef] [PubMed]

107. Van Camp, G.; Snoeckx, R.L.; Hilgert, N.; van den Ende, J.; Fukuoka, H.; Wagatsuma, M.; Suzuki, H.; Smets, R.M.; Vanhoenacker, F.; Declau, F.; et al. A new autosomal recessive form of Stickler syndrome is caused by a mutation in the COL9A1 gene. Am. J. Hum. Genet. 2006, 79, 449-457. [CrossRef] [PubMed]

108. Nikopoulos, K.; Schrauwen, I.; Simon, M.; Collin, R.W.; Veckeneer, M.; Keymolen, K.; Van Camp, G.; Cremers, F.P.; van den Born, L.I. Autosomal recessive Stickler syndrome in two families is caused by mutations in the COL9A1 gene. Investig. Ophthalmol. Vis. Sci. 2011, 52, 4774-4779. [CrossRef]

109. Baker, S.; Booth, C.; Fillman, C.; Shapiro, M.; Blair, M.P.; Hyland, J.C.; Ala-Kokko, L. A loss of function mutation in the COL9A2 gene causes autosomal recessive Stickler syndrome. Am. J. Med. Genet. A 2011, 155, 1668-1672. [CrossRef] [PubMed]

110. Stickler, G.B.; Hughes, W.; Houchin, P. Clinical features of hereditary progressive arthro-ophthalmopathy (Stickler syndrome): A survey. Genet. Med. 2001, 3, 192-196. [CrossRef] 
111. Poulson, A.V.; Hooymans, J.M.; Richards, A.J.; Bearcroft, P.; Murthy, R.; Baguley, D.M.; Scott, J.D.; Snead, M.P. Clinical features of type 2 Stickler syndrome. J. Med. Genet. 2004, 41, e107. [CrossRef]

112. Seery, C.M.; Pruett, R.C.; Liberfarb, R.M.; Cohen, B.Z. Distinctive cataract in the Stickler syndrome. Am. J. Ophthalmol. 1990, 110, 143-148. [CrossRef]

113. Scott, J.D. Duke-Elder lecture. Prevention and perspective in retinal detachment. Eye (London) 1989, 3 Pt 5, 491-515. [CrossRef] [PubMed]

114. Ang, A.; Poulson, A.V.; Goodburn, S.F.; Richards, A.J.; Scott, J.D.; Snead, M.P. Retinal detachment and prophylaxis in type 1 Stickler syndrome. Ophthalmology 2008, 115, 164-168. [CrossRef] [PubMed]

115. Spallone, A. Stickler's syndrome: A study of 12 families. Br. J. Ophthalmol. 1987, 71, 504-509. [CrossRef] [PubMed]

116. Zechi-Ceide, R.M.; Jesus Oliveira, N.A.; Guion-Almeida, M.L.; Antunes, L.F.; Richieri-Costa, A.; Passos-Bueno, M.R. Clinical evaluation and COL2A1 gene analysis in 21 Brazilian families with Stickler syndrome: Identification of novel mutations, further genotype/phenotype correlation, and its implications for the diagnosis. Eur. J. Med. Genet. 2008, 51, 183-196. [CrossRef]

117. Temple, I.K. Stickler's syndrome. J. Med. Genet. 1989, 26, 119-126. [CrossRef]

118. Reddy, D.N.; Yonekawa, Y.; Thomas, B.J.; Nudleman, E.D.; Williams, G.A. Long-term surgical outcomes of retinal detachment in patients with Stickler syndrome. Clin. Ophthalmol. 2016, 10, 1531-1534. [CrossRef]

119. Abeysiri, P.; Bunce, C.; da Cruz, L. Outcomes of surgery for retinal detachment in patients with Stickler syndrome: A comparison of two sequential 20-year cohorts. Graefes Arch. Clin. Exp. Ophthalmol. 2007, 245, 1633-1638. [CrossRef]

120. Shenoy, B.; Mandal, A.K. Stickler syndrome associated with congenital glaucoma. Lancet 2013, 381, 422. [CrossRef]

121. Ziakas, N.G.; Ramsay, A.S.; Lynch, S.A.; Clarke, M.P. Stickler's syndrome associated with congenital glaucoma. Ophthalmic Genet. 1998, 19, 55-58. [CrossRef] [PubMed]

122. Wubben, T.J.; Branham, K.H.; Besirli, C.G.; Bohnsack, B.L. Retinal detachment and infantile-onset glaucoma in Stickler syndrome associated with known and novel COL2A1 mutations. Ophthalmic Genet. 2018, 39, 615-618. [CrossRef]

123. Treurniet, S.; Burger, P.; Ghyczy, E.A.E.; Verbraak, F.D.; Curro-Tafili, K.R.; Micha, D.; Bravenboer, N.; Ralston, S.H.; de Vries, R.; Moll, A.C.; et al. Ocular characteristics and complications in patients with osteogenesis imperfecta: A systematic review. Acta Ophthalmol. 2021. [CrossRef]

124. van Dijk, F.S.; Cobben, J.M.; Maugeri, A.; Nikkels, P.G.; van Rijn, R.R.; Pals, G. Osteogenesis imperfecta: Clinical and genetic heterogeneity. Ned. Tijdschr. Geneeskd. 2012, 156, A4585. [PubMed]

125. Carre, F.; Achard, S.; Rouillon, I.; Parodi, M.; Loundon, N. Hearing impairment and osteogenesis imperfecta: Literature review. Eur. Ann. Otorhinolaryngol. Head Neck Dis. 2019, 136, 379-383. [CrossRef] [PubMed]

126. Lund, A.M.; Jensen, B.L.; Nielsen, L.A.; Skovby, F. Dental manifestations of osteogenesis imperfecta and abnormalities of collagen I metabolism. J. Craniofac. Genet. Dev. Biol. 1998, 18, 30-37. [PubMed]

127. Sillence, D.O.; Rimoin, D.L.; Danks, D.M. Clinical variability in osteogenesis imperfecta-variable expressivity or genetic heterogeneity. Birth Defects Orig. Artic. Ser. 1979, 15, 113-129.

128. Van Dijk, F.S.; Sillence, D.O. Osteogenesis imperfecta: Clinical diagnosis, nomenclature and severity assessment. Am. J. Med. Genet. A 2014, 164, 1470-1481. [CrossRef]

129. Hald, J.D.; Folkestad, L.; Swan, C.Z.; Wanscher, J.; Schmidt, M.; Gjorup, H.; Haubek, D.; Leonhard, C.H.; Larsen, D.A.; Hjortdal, J.O.; et al. Osteogenesis imperfecta and the teeth, eyes, and ears-a study of non-skeletal phenotypes in adults. Osteoporos. Int. 2018, 29, 2781-2789. [CrossRef]

130. Evereklioglu, C.; Madenci, E.; Bayazit, Y.A.; Yilmaz, K.; Balat, A.; Bekir, N.A. Central corneal thickness is lower in osteogenesis imperfecta and negatively correlates with the presence of blue sclera. Ophthalmic Physiol. Opt. 2002, 22, 511-515. [CrossRef]

131. Dimasi, D.P.; Chen, J.Y.; Hewitt, A.W.; Klebe, S.; Davey, R.; Stirling, J.; Thompson, E.; Forbes, R.; Tan, T.Y.; Savarirayan, R.; et al. Novel quantitative trait loci for central corneal thickness identified by candidate gene analysis of osteogenesis imperfecta genes. Hum. Genet. 2010, 127, 33-44. [CrossRef]

132. Wenstrup, R.J.; Willing, M.C.; Starman, B.J.; Byers, P.H. Distinct biochemical phenotypes predict clinical severity in nonlethal variants of osteogenesis imperfecta. Am. J. Hum. Genet. 1990, 46, 975-982.

133. Beighton, P. Familial dentinogenesis imperfecta, blue sclerae, and wormian bones without fractures: Another type of osteogenesis imperfecta? J. Med. Genet. 1981, 18, 124-128. [CrossRef]

134. Sillence, D.; Butler, B.; Latham, M.; Barlow, K. Natural history of blue sclerae in osteogenesis imperfecta. Am. J. Med. Genet. 1993, 45, 183-186. [CrossRef]

135. Kaiser-Kupfer, M.I.; Podgor, M.J.; McCain, L.; Kupfer, C.; Shapiro, J.R. Correlation of ocular rigidity and blue sclerae in osteogenesis imperfecta. Trans. Ophthalmol. Soc. UK 1985, 104 Pt 2, 191-195.

136. Kaiser-Kupfer, M.I.; McCain, L.; Shapiro, J.R.; Podgor, M.J.; Kupfer, C.; Rowe, D. Low ocular rigidity in patients with osteogenesis imperfecta. Invest. Ophthalmol. Vis. Sci. 1981, 20, 807-809. [PubMed]

137. Eliott, D.; Rezai, K.A.; Dass, A.B.; Lewis, J. Management of retinal detachment in osteogenesis imperfecta. Arch. Ophthalmol. 2003, 121, 1062-1064. [CrossRef] [PubMed]

138. Fleissig, E.; Barak, A. Surgical Management of Retinal Detachment in Osteogenesis Imperfecta: Case Report and Review of the Literature. Retin. Cases Brief Rep. 2019, 13, 43-46. [CrossRef] [PubMed]

139. Jonisch, J.; Deramo, V.A. Sutureless 25-gauge vitrectomy for retinal detachment repair in a patient with osteogenesis imperfecta. Retin. Cases Brief Rep. 2011, 5, 67-69. [CrossRef] [PubMed] 
140. Church, J.R.; Winder, S.M. Surgical repair of a retinal detachment in a patient with osteogenesis imperfecta. Retina 2006, 26, 242-243. [CrossRef]

141. Madigan, W.P.; Wertz, D.; Cockerham, G.C.; Thach, A.B. Retinal detachment in osteogenesis imperfecta. J. Pediatr. Ophthalmol. Strabismus 1994, 31, 268-269. [CrossRef]

142. Mauri, L.; Uebe, S.; Sticht, H.; Vossmerbaeumer, U.; Weisschuh, N.; Manfredini, E.; Maselli, E.; Patrosso, M.; Weinreb, R.N.; Penco, S.; et al. Expanding the clinical spectrum of COL1A1 mutations in different forms of glaucoma. Orphanet. J. Rare Dis. 2016, 11, 108. [CrossRef]

143. Bohnsack, B.L. Infantile-onset glaucoma and anterior megalophthalmos in osteogenesis imperfecta. J. AAPOS 2016, 20, 170-172. [CrossRef] [PubMed]

144. Meuwissen, M.E.; Halley, D.J.; Smit, L.S.; Lequin, M.H.; Cobben, J.M.; de Coo, R.; van Harssel, J.; Sallevelt, S.; Woldringh, G.; van der Knaap, M.S.; et al. The expanding phenotype of COL4A1 and COL4A2 mutations: Clinical data on 13 newly identified families and a review of the literature. Genet. Med. 2015, 17, 843-853. [CrossRef] [PubMed]

145. Mao, M.; Kiss, M.; Ou, Y.; Gould, D.B. Genetic dissection of anterior segment dysgenesis caused by a Col4a1 mutation in mouse. Dis. Model. Mech. 2017, 10, 475-485. [CrossRef] [PubMed]

146. Souma, T.; Tompson, S.W.; Thomson, B.R.; Siggs, O.M.; Kizhatil, K.; Yamaguchi, S.; Feng, L.; Limviphuvadh, V.; Whisenhunt, K.N.; Maurer-Stroh, S.; et al. Angiopoietin receptor TEK mutations underlie primary congenital glaucoma with variable expressivity. $J$. Clin. Investig. 2016, 126, 2575-2587. [CrossRef] [PubMed]

147. Thomson, B.R.; Souma, T.; Tompson, S.W.; Onay, T.; Kizhatil, K.; Siggs, O.M.; Feng, L.; Whisenhunt, K.N.; Yanovitch, T.L.; Kalaydjieva, L.; et al. Angiopoietin-1 is required for Schlemm's canal development in mice and humans. J. Clin. Investig. 2017, 127, 4421-4436. [CrossRef]

148. Limaye, N.; Wouters, V.; Uebelhoer, M.; Tuominen, M.; Wirkkala, R.; Mulliken, J.B.; Eklund, L.; Boon, L.M.; Vikkula, M. Somatic mutations in angiopoietin receptor gene TEK cause solitary and multiple sporadic venous malformations. Nat. Genet. 2009, 41, 118-124. [CrossRef]

149. Aicardi, J.; Goutieres, F. A progressive familial encephalopathy in infancy with calcifications of the basal ganglia and chronic cerebrospinal fluid lymphocytosis. Ann. Neurol. 1984, 15, 49-54. [CrossRef]

150. Crow, Y.J.; Leitch, A.; Hayward, B.E.; Garner, A.; Parmar, R.; Griffith, E.; Ali, M.; Semple, C.; Aicardi, J.; Babul-Hirji, R.; et al. Mutations in genes encoding ribonuclease $\mathrm{H} 2$ subunits cause Aicardi-Goutieres syndrome and mimic congenital viral brain infection. Nat. Genet. 2006, 38, 910-916. [CrossRef]

151. Rice, G.I.; Del Toro Duany, Y.; Jenkinson, E.M.; Forte, G.M.; Anderson, B.H.; Ariaudo, G.; Bader-Meunier, B.; Baildam, E.M.; Battini, R.; Beresford, M.W.; et al. Gain-of-function mutations in IFIH1 cause a spectrum of human disease phenotypes associated with upregulated type I interferon signaling. Nat. Genet. 2014, 46, 503-509. [CrossRef]

152. Rice, G.I.; Park, S.; Gavazzi, F.; Adang, L.A.; Ayuk, L.A.; Van Eyck, L.; Seabra, L.; Barrea, C.; Battini, R.; Belot, A.; et al. Genetic and phenotypic spectrum associated with IFIH1 gain-of-function. Hum. Mutat 2020, 41, 837-849. [CrossRef]

153. Crow, Y.J.; Chase, D.S.; Lowenstein Schmidt, J.; Szynkiewicz, M.; Forte, G.M.; Gornall, H.L.; Oojageer, A.; Anderson, B.; Pizzino, A.; Helman, G.; et al. Characterization of human disease phenotypes associated with mutations in TREX1, RNASEH2A, RNASEH2B, RNASEH2C, SAMHD1, ADAR, and IFIH1. Am. J. Med. Genet. A 2015, 167, 296-312. [CrossRef] [PubMed]

154. Singleton, E.B.; Merten, D.F. An unusual syndrome of widened medullary cavities of the metacarpals and phalanges, aortic calcification and abnormal dentition. Pediatr. Radiol. 1973, 1, 2-7. [CrossRef]

155. Jang, M.A.; Kim, E.K.; Now, H.; Nguyen, N.T.; Kim, W.J.; Yoo, J.Y.; Lee, J.; Jeong, Y.M.; Kim, C.H.; Kim, O.H.; et al. Mutations in DDX58, which encodes RIG-I, cause atypical Singleton-Merten syndrome. Am. J. Hum. Genet. 2015, 96, 266-274. [CrossRef]

156. Feigenbaum, A.; Muller, C.; Yale, C.; Kleinheinz, J.; Jezewski, P.; Kehl, H.G.; MacDougall, M.; Rutsch, F.; Hennekam, R.C. Singleton-Merten syndrome: An autosomal dominant disorder with variable expression. Am. J. Med. Genet. A 2013, 161, 360-370. [CrossRef]

157. Rutsch, F.; MacDougall, M.; Lu, C.; Buers, I.; Mamaeva, O.; Nitschke, Y.; Rice, G.I.; Erlandsen, H.; Kehl, H.G.; Thiele, H.; et al. A specific IFIH1 gain-of-function mutation causes Singleton-Merten syndrome. Am. J. Hum. Genet. 2015, 96, 275-282. [CrossRef] [PubMed]

158. Prasov, L.; Bohnsack, B.L.; El Husny, A.S.; Tsoi, L.C.; Guan, B.; Kahlenberg, J.M.; Almeida, E.; Wang, H.; Cowen, E.W.; De Jesus, A.A.; et al. DDX58(RIG-I)-related disease is associated with tissue-specific interferon pathway activation. J. Med. Genet. 2021. [CrossRef]

159. Ferreira, C.R.; Crow, Y.J.; Gahl, W.A.; Gardner, P.J.; Goldbach-Mansky, R.; Hur, S.; de Jesus, A.A.; Nehrebecky, M.; Park, J.W.; Briggs, T.A. DDX58 and Classic Singleton-Merten Syndrome. J. Clin. Immunol. 2019, 39, 75-80. [CrossRef]

160. Vanderver, A.; Adang, L.; Gavazzi, F.; McDonald, K.; Helman, G.; Frank, D.B.; Jaffe, N.; Yum, S.W.; Collins, A.; Keller, S.R.; et al. Janus Kinase Inhibition in the Aicardi-Goutieres Syndrome. N. Engl. J. Med. 2020, 383, 986-989. [CrossRef] [PubMed]

161. Abu Tayeh, A.; Funabiki, M.; Shimizu, S.; Satoh, S.; Sumin, L.; Iwakura, Y.; Kato, H.; Fujita, T. Psoriasis-like skin disorder in transgenic mice expressing a RIG-I Singleton-Merten syndrome variant. Int. Immunol. 2021, 33, 211-224. [CrossRef]

162. Carricondo, P.C.; Andrade, T.; Prasov, L.; Ayres, B.M.; Moroi, S.E. Nanophthalmos: A Review of the Clinical Spectrum and Genetics. J. Ophthalmol. 2018, 2018, 2735465. [CrossRef] [PubMed]

163. Hammond, C.J.; Snieder, H.; Gilbert, C.E.; Spector, T.D. Genes and environment in refractive error: The twin eye study. Investig. Ophthalmol. Vis. Sci. 2001, 42, 1232-1236. 
164. Klein, A.P.; Suktitipat, B.; Duggal, P.; Lee, K.E.; Klein, R.; Bailey-Wilson, J.E.; Klein, B.E. Heritability analysis of spherical equivalent, axial length, corneal curvature, and anterior chamber depth in the Beaver Dam Eye Study. Arch. Ophthalmol. 2009, 127, 649-655. [CrossRef]

165. Gal, A.; Rau, I.; El Matri, L.; Kreienkamp, H.J.; Fehr, S.; Baklouti, K.; Chouchane, I.; Li, Y.; Rehbein, M.; Fuchs, J.; et al. Autosomalrecessive posterior microphthalmos is caused by mutations in PRSS56, a gene encoding a trypsin-like serine protease. Am. J. Hum. Genet. 2011, 88, 382-390. [CrossRef]

166. Nair, K.S.; Hmani-Aifa, M.; Ali, Z.; Kearney, A.L.; Ben Salem, S.; Macalinao, D.G.; Cosma, I.M.; Bouassida, W.; Hakim, B.; Benzina, Z.; et al. Alteration of the serine protease PRSS56 causes angle-closure glaucoma in mice and posterior microphthalmia in humans and mice. Nat. Genet. 2011, 43, 579-584. [CrossRef] [PubMed]

167. Sundin, O.H.; Leppert, G.S.; Silva, E.D.; Yang, J.M.; Dharmaraj, S.; Maumenee, I.H.; Santos, L.C.; Parsa, C.F.; Traboulsi, E.I.; Broman, K.W.; et al. Extreme hyperopia is the result of null mutations in MFRP, which encodes a Frizzled-related protein. Proc. Natl. Acad. Sci. USA 2005, 102, 9553-9558. [CrossRef]

168. Garnai, S.J.; Brinkmeier, M.L.; Emery, B.; Aleman, T.S.; Pyle, L.C.; Veleva-Rotse, B.; Sisk, R.A.; Rozsa, F.W.; Ozel, A.B.; Li, J.Z.; et al. Variants in myelin regulatory factor (MYRF) cause autosomal dominant and syndromic nanophthalmos in humans and retinal degeneration in mice. PLoS Genet. 2019, 15, e1008130. [CrossRef] [PubMed]

169. Xiao, X.; Sun, W.; Ouyang, J.; Li, S.; Jia, X.; Tan, Z.; Hejtmancik, J.F.; Zhang, Q. Novel truncation mutations in MYRF cause autosomal dominant high hyperopia mapped to 11p12-q13.3. Hum. Genet. 2019, 138, 1077-1090. [CrossRef]

170. Isojima, T.; Doi, K.; Mitsui, J.; Oda, Y.; Tokuhiro, E.; Yasoda, A.; Yorifuji, T.; Horikawa, R.; Yoshimura, J.; Ishiura, H.; et al. A recurrent de novo FAM111A mutation causes Kenny-Caffey syndrome type 2. J. Bone Miner. Res. 2014, 29, 992-998. [CrossRef]

171. Othman, M.I.; Sullivan, S.A.; Skuta, G.L.; Cockrell, D.A.; Stringham, H.M.; Downs, C.A.; Fornes, A.; Mick, A.; Boehnke, M.; Vollrath, D.; et al. Autosomal dominant nanophthalmos (NNO1) with high hyperopia and angle-closure glaucoma maps to chromosome 11. Am. J. Hum. Genet. 1998, 63, 1411-1418. [CrossRef] [PubMed]

172. Pinz, H.; Pyle, L.C.; Li, D.; Izumi, K.; Skraban, C.; Tarpinian, J.; Braddock, S.R.; Telegrafi, A.; Monaghan, K.G.; Zackai, E.; et al. De novo variants in Myelin regulatory factor (MYRF) as candidates of a new syndrome of cardiac and urogenital anomalies. Am. $J$. Med. Genet. A 2018, 176, 969-972. [CrossRef]

173. Qi, H.; Yu, L.; Zhou, X.; Wynn, J.; Zhao, H.; Guo, Y.; Zhu, N.; Kitaygorodsky, A.; Hernan, R.; Aspelund, G.; et al. De novo variants in congenital diaphragmatic hernia identify MYRF as a new syndrome and reveal genetic overlaps with other developmental disorders. PLoS Genet. 2018, 14, e1007822. [CrossRef] [PubMed]

174. Kenny, F.M.; Linarelli, L. Dwarfism and cortical thickening of tubular bones. Transient hypocalcemia in a mother and son. Am. J. Dis Child. 1966, 111, 201-207. [CrossRef]

175. Unger, S.; Gorna, M.W.; Le Bechec, A.; Do Vale-Pereira, S.; Bedeschi, M.F.; Geiberger, S.; Grigelioniene, G.; Horemuzova, E.; Lalatta, F.; Lausch, E.; et al. FAM111A mutations result in hypoparathyroidism and impaired skeletal development. Am. J. Hum. Genet. 2013, 92, 990-995. [CrossRef] [PubMed]

176. Almoallem, B.; Arno, G.; De Zaeytijd, J.; Verdin, H.; Balikova, I.; Casteels, I.; de Ravel, T.; Hull, S.; Suzani, M.; Destree, A.; et al. The majority of autosomal recessive nanophthalmos and posterior microphthalmia can be attributed to biallelic sequence and structural variants in MFRP and PRSS56. Sci. Rep. 2020, 10, 1289. [CrossRef] [PubMed]

177. Prasov, L.; Guan, B.; Ullah, E.; Archer, S.M.; Ayres, B.M.; Besirli, C.G.; Wiinikka-Buesser, L.; Comer, G.M.; Del Monte, M.A.; Elner, S.G.; et al. Novel TMEM98, MFRP, PRSS56 variants in a large United States high hyperopia and nanophthalmos cohort. Sci. Rep. 2020, 10, 19986. [CrossRef] [PubMed]

178. Siggs, O.M.; Awadalla, M.S.; Souzeau, E.; Staffieri, S.E.; Kearns, L.S.; Laurie, K.; Kuot, A.; Qassim, A.; Edwards, T.L.; Coote, M.A.; et al. The genetic and clinical landscape of nanophthalmos and posterior microphthalmos in an Australian cohort. Clin. Genet. 2020, 97, 764-769. [CrossRef] [PubMed]

179. Hoffman, R.S.; Vasavada, A.R.; Allen, Q.B.; Snyder, M.E.; Devgan, U.; Braga-Mele, R.; ASCRS Cataract Clinical Committee. Cataract surgery in the small eye. J. Cataract. Refract. Surg. 2015, 41, 2565-2575. [CrossRef] [PubMed]

180. Crespi, J.; Buil, J.A.; Bassaganyas, F.; Vela-Segarra, J.I.; Diaz-Cascajosa, J.; Ayala-Ramirez, R.; Zenteno, J.C. A novel mutation confirms MFRP as the gene causing the syndrome of nanophthalmos-renititis pigmentosa-foveoschisis-optic disk drusen. Am. J. Ophthalmol. 2008, 146, 323-328. [CrossRef]

181. Ayala-Ramirez, R.; Graue-Wiechers, F.; Robredo, V.; Amato-Almanza, M.; Horta-Diez, I.; Zenteno, J.C. A new autosomal recessive syndrome consisting of posterior microphthalmos, retinitis pigmentosa, foveoschisis, and optic disc drusen is caused by a MFRP gene mutation. Mol. Vis. 2006, 12, 1483-1489. [PubMed]

182. Yardley, J.; Leroy, B.P.; Hart-Holden, N.; Lafaut, B.A.; Loeys, B.; Messiaen, L.M.; Perveen, R.; Reddy, M.A.; Bhattacharya, S.S.; Traboulsi, E.; et al. Mutations of VMD2 splicing regulators cause nanophthalmos and autosomal dominant vitreoretinochoroidopathy (ADVIRC). Investig. Ophthalmol. Vis. Sci. 2004, 45, 3683-3689. [CrossRef]

183. Hendriks, M.; Verhoeven, V.J.M.; Buitendijk, G.H.S.; Polling, J.R.; Meester-Smoor, M.A.; Hofman, A.; Consortium, R.D.; Kamermans, M.; Ingeborgh van den Born, L.; Klaver, C.C.W. Development of Refractive Errors-What Can We Learn from Inherited Retinal Dystrophies? Am. J. Ophthalmol. 2017, 182, 81-89. [CrossRef]

184. Aleman, T.S.; Uyhazi, K.E.; Serrano, L.W.; Vasireddy, V.; Bowman, S.J.; Ammar, M.J.; Pearson, D.J.; Maguire, A.M.; Bennett, J. RDH12 Mutations Cause a Severe Retinal Degeneration With Relatively Spared Rod Function. Investig. Ophthalmol. Vis. Sci. 2018, 59, 5225-5236. [CrossRef] [PubMed] 
185. Russell-Eggitt, I.M.; Clayton, P.T.; Coffey, R.; Kriss, A.; Taylor, D.S.; Taylor, J.F. Alstrom syndrome. Report of 22 cases and literature review. Ophthalmology 1998, 105, 1274-1280. [CrossRef]

186. Wu, W.; Dawson, D.G.; Sugar, A.; Elner, S.G.; Meyer, K.A.; McKey, J.B.; Moroi, S.E. Cataract surgery in patients with nanophthalmos: Results and complications. J. Cataract. Refract. Surg. 2004, 30, 584-590. [CrossRef] [PubMed]

187. Rajendrababu, S.; Shroff, S.; Uduman, M.S.; Babu, N. Clinical spectrum and treatment outcomes of patients with nanophthalmos. Eye (London) 2021, 35, 825-830. [CrossRef] [PubMed]

188. Velez, G.; Tsang, S.H.; Tsai, Y.T.; Hsu, C.W.; Gore, A.; Abdelhakim, A.H.; Mahajan, M.; Silverman, R.H.; Sparrow, J.R.; Bassuk, A.G.; et al. Gene Therapy Restores Mfrp and Corrects Axial Eye Length. Sci. Rep. 2017, 7, 16151. [CrossRef] [PubMed] 